Article

Subscriber access provided by Lib4RI - Library for Eawag, Empa, PSI \& WSL

\title{
Sulfur poisoning recovery on a SOFC anode material through reversible segregation of nickel
}

Patrick Steiger, Dariusz Burnat, Hossein Madi, Andreas Mai, Lorenz Holzer, Jan Van Herle, Oliver Kröcher, Andre Heel, and Davide Ferri

Chem. Mater., Just Accepted Manuscript • DOI: 10.1021/acs.chemmater.8b03669 • Publication Date (Web): 06 Jan 2019

Downloaded from http://pubs.acs.org on January 9, 2019

\section{Just Accepted}

"Just Accepted" manuscripts have been peer-reviewed and accepted for publication. They are posted online prior to technical editing, formatting for publication and author proofing. The American Chemical Society provides "Just Accepted" as a service to the research community to expedite the dissemination of scientific material as soon as possible after acceptance. "Just Accepted" manuscripts appear in full in PDF format accompanied by an HTML abstract. "Just Accepted" manuscripts have been fully peer reviewed, but should not be considered the official version of record. They are citable by the Digital Object Identifier (DOI®). "Just Accepted" is an optional service offered to authors. Therefore, the "Just Accepted" Web site may not include all articles that will be published in the journal. After a manuscript is technically edited and formatted, it will be removed from the "Just Accepted" Web site and published as an ASAP article. Note that technical editing may introduce minor changes to the manuscript text and/or graphics which could affect content, and all legal disclaimers and ethical guidelines that apply to the journal pertain. ACS cannot be held responsible for errors or consequences arising from the use of information contained in these "Just Accepted" manuscripts. 


\title{
Sulfur poisoning recovery on a SOFC anode material through reversible segregation of nickel
}

\author{
Patrick Steiger $^{\mathrm{a}, \mathrm{b}}$, Dariusz Burnat ${ }^{\mathrm{c}}$, Hossein Madi ${ }^{\mathrm{d}}$, Andreas Mai ${ }^{\mathrm{e}}$, Lorenz Holzer ${ }^{\mathrm{f}}$, Jan Van \\ Herle $^{\mathrm{d}}$, Oliver Kröcher ${ }^{\mathrm{a}, \mathrm{b}}$, Andre $\mathrm{Heel}^{\mathrm{c}}$, and Davide Ferria*
}

a Paul Scherrer Institut, CH-5232 Villigen, Switzerland

b École polytechnique fédérale de Lausanne (EFPL), Institute of Chemical Sciences and Engineering, CH-1015 Lausanne, Switzerland

c Zurich University of Applied Sciences, IMPE - Institute for Materials and Process Engineering, CH-8400 Winterthur, Switzerland

d École polytechnique fédérale de Lausanne (EFPL), Institute of Mechanical Engineering, CH-1951 Sion, Switzerland

e HEXIS AG, CH-8404 Winterthur Switzerland

f Zurich University of Applied Sciences, ICP - Institute of Computational Physics, CH8400 Winterthur, Switzerland

* Corresponding author e-mail: davide.ferri@psi.ch

Phone: +41 563102781 


\begin{abstract}
The perovskite-type mixed oxide $\mathrm{La}_{0.3} \mathrm{Sr}_{0.55} \mathrm{Ti}_{0.95} \mathrm{Ni}_{0.05} \mathrm{O}_{3-\delta}$ (LSTN) is demonstrated to exhibit the remarkable property of structural regeneration, where Ni can be reversibly exsoluted from the host perovskite lattice resulting in a regenerable $\mathrm{Ni}$ catalyst for solid oxide fuel cell anode applications. Results of catalytic tests for the water gas shift reaction and electrochemical investigations on a button sized fuel cell demonstrate the redox stability of LSTN, its potential application in solid oxide fuel cells and its ability to recover catalytic activity completely after sulfur poisoning. Nickel segregation was characterized and quantified on powder samples by means of electron microscopy, X-ray diffraction, $\mathrm{X}$-ray absorption spectroscopy as well as temperature programmed reduction - reoxidation cycles. Catalyst stability was much improved compared to impregnated $\mathrm{Ni} / \mathrm{La}_{0.3} \mathrm{Sr}_{0.55} \mathrm{TiO}_{3-\delta}$ and $\mathrm{Ni} / \mathrm{Y}_{0.08} \mathrm{Zr}_{0.92} \mathrm{O}_{2}$ anode materials. A full cell was tested under both open circuit voltage and polarized conditions showing a stable cell voltage over redox cycles as well as periods of reverse potential and current overload. The area specific resistance of the anode layer was as low as $0.58 \Omega \mathrm{cm}^{2}$ at $850^{\circ} \mathrm{C}$. This allows LSTN to be applied in redox stable solid oxide fuel cell anodes and reversible segregation of $\mathrm{Ni}$ to be exploited for fast recovery from sulfur poisoning.
\end{abstract}




\section{Introduction}

Modern society relies on the development of highly efficient and stable power sources ideally capable of using variable fuel sources to meet the ever increasing electricity demand. ${ }^{1-2}$ Solid oxide fuel cells (SOFC) offer exceptionally high efficiency for chemical to electric power conversion with high fuel flexibility. ${ }^{3-5}$ Unlike other types of fuel cells their high operating temperatures allow for hydrocarbon fuels from various sources to be directly used via internal reforming reactions ${ }^{6-7}$ producing hydrogen and carbon monoxide mixture fuels. This is a major advantage over polymer electrolyte fuel cells (PEM), which rely on highly pure hydrogen as fuel gas. ${ }^{8}$ Internal reforming occurs at the SOFC anode, $\mathrm{Ni}$ metal catalyzes this reaction as well as the important hydrogen oxidation reaction $\left(\mathrm{H}_{2}+1 / 2 \mathrm{O}_{2} \rightarrow \mathrm{H}_{2} \mathrm{O}, \mathrm{HOR}\right)$ and the water gas shift reaction $\left(\mathrm{CO}+\mathrm{H}_{2} \mathrm{O} \rightarrow \mathrm{CO}_{2}+\mathrm{H}_{2}\right.$, WGS), which produces additional $\mathrm{H}_{2}$ fuel from residual steam originating from reforming or water generated through HOR. ${ }^{9}$ Besides catalytic activity, the anode material has to provide also both, high ionic and electronic conductivity for the electrochemical oxidation of the fuel gas and for current collection, respectively. For a long time $\mathrm{Ni} / \mathrm{Y}_{0.08} \mathrm{Zr}_{0.92} \mathrm{O}_{2}$ (Ni/YSZ) cermets have been the state-of-the-art anode material offering both high catalytic activity (due to addition of a considerable amount of $\mathrm{Ni}$, ca. $50 \mathrm{wt} \%$ ) as well as good conductivity for both electrons and oxygen anions provided by the percolating Ni and YSZ phases, respectively. ${ }^{10-12}$ However, their poor redox stability is regarded as a major disadvantage besides their susceptibility to poisoning by sulfur. ${ }^{13-14}$ Sulfur contaminants are commonly present in fuel gas as they are used as odorants for natural gas or may be present in large quantities in biogenic fuels. At low concentrations sulfur species are known to strongly adsorb on the Ni surface thus deactivating the metal catalyst. ${ }^{15-18}$ High sulfur concentrations may induce the formation of sulfur compounds (e.g. $\mathrm{NiS}, \mathrm{Ni}_{3} \mathrm{~S}_{2}$ and $\mathrm{Ni}_{7} \mathrm{~S}_{6}$ ) that permanently degrade $\mathrm{Ni}$ containing SOFC anodes not only with respect to catalytic activity for hydrogen oxidation but especially for WGS. ${ }^{17-18}$ Sulfur was also 
observed to promote the migration of $\mathrm{Ni}$, thus decreasing the degree of Ni percolation within the anode and reducing electronic conductivity. ${ }^{19}$

For these reasons much attention is currently drawn to the development of novel SOFC anode materials capable to offer the required electrochemical performance and stability in sulfur containing feeds. Other beneficial properties such as redox stability could be potentially exploited as it would allow operating the cell in electrolysis mode but also regenerating a deactivated anode from sulfur poisoning and/or coke deposits, which may have formed during internal reforming of hydrocarbons. Reduction of overall Ni content is essential to achieve redox stability. Besides the coarsening of the Ni phase, the oxidation of $\mathrm{Ni}$ and consequential volume expansion of the $\mathrm{Ni}$ phase may lead to electrode or electrolyte cracking. ${ }^{13-14,20-22}$ Perovskite-type oxides $\left(\mathrm{ABO}_{3}\right)$ are regarded as good candidates to replace high Ni content anode cermets with the aim of increasing anode durability. ${ }^{23-25}$ Their inherent structural stability allows for a large number of elements to be incorporated at various stoichiometries within their lattice and thus ultimately for the tailoring of both electronic and ionic conductivities besides catalytic properties. Among others, lanthanum doped strontium titanates have attracted attention since they are temperature and redox stable and offer the necessary conductivities required for SOFC electrode applications. ${ }^{23}$ Nickel can still be added for its catalytic activity and is deposited on the perovskite backbone in the form of nanoparticles usually by impregnation. ${ }^{25-27}$

In more recent years direct $\mathrm{Ni}$ exsolution from the perovskite lattice through selective reduction has been shown to produce particles with enhanced sintering and coking resistance. ${ }^{28-32}$ Exsolution from perovskite-type mixed oxides is achieved by partially substituting the B-site elements of a redox stable perovskite host lattice by $\mathrm{Ni}$ and subjecting these materials to a reductive environment. This causes the dispersed $\mathrm{Ni}$ within the perovskite to reduce and segregate forming well dispersed particles on the perovskite surface, while the rest of the perovskite remains intact and structurally stable. Segregated Ni particles show much higher particle-support interactions compared to Ni particles deposited through 
conventional support impregnation methods, as they remain partially embedded in the surface of the perovskite material, which pins them in place. ${ }^{28}$ Some perovskite-type oxides have also been shown to exhibit the remarkable property of structural self-regeneration, i.e. the reversible reincorporation of such particles into the perovskite lattice. This capability was shown to depend on both composition of the host perovskite as well as on the regeneration conditions (i.e. oxygen partial pressure and temperature) and has been demonstrated for a variety of Pt group metals for exhaust gas after treatment catalysts and recently for $\mathrm{Fe}$ and $\mathrm{Co} \cdot{ }^{33-37} \mathrm{Ni}$ has also been shown to segregate and reincorporate reversibly during simple redox cycles from $\mathrm{LaFe}_{1-\mathrm{x}} \mathrm{Ni}_{\mathrm{x}} \mathrm{O}_{3 \pm \delta}$ perovskite-type oxides ${ }^{38-39}$ and more recently $\mathrm{La}_{0.7} \mathrm{Sr}_{0.3} \mathrm{Cr}_{1-\mathrm{x}} \mathrm{Ni}_{\mathrm{x}} \mathrm{O}_{3-\delta}{ }^{40}$ Exploitation of this effect produced highly redox stable catalysts, enabling the preservation of metal particle size and thus activity over repeated redox cycles.

The objective of this work was to demonstrate that, if a material with such a property was applied as a SOFC anode, anode reoxidation at high temperatures could be utilized to remove poisoning (such as $\mathrm{H}_{2} \mathrm{~S}$ ) from its surface through simple reoxidation as well as allowing the cell to be operated in electrolysis mode. We demonstrate that $\mathrm{La}_{0.3} \mathrm{Sr}_{0.55} \mathrm{Ti}_{0.95} \mathrm{Ni}_{0.05} \mathrm{O}_{3-\delta}$ exhibits all the properties required for operation as SOFC anode and verify the advantage of structural self-regeneration. This property can indeed be exploited on this perovskite-type host to restore the catalytic activity of Ni towards the water gas shift reaction after sulfur poisoning and to produce redox stable SOFCs. 


\section{Experimental details}

Mixed metal oxides with nominal composition $\mathrm{La}_{0.3} \mathrm{Sr}_{0.55} \mathrm{TiO}_{3-\delta}$ (LST) and $\mathrm{La}_{0.3} \mathrm{Sr}_{0.55} \mathrm{Ti}_{0.95} \mathrm{Ni}_{0.05} \mathrm{O}_{3-\delta}$ (LSTN) were synthesized using a citrate-gel method described including a final calcination step at $960^{\circ} \mathrm{C}$ for 6 h. ${ }^{30}$ After calcination the powders are referred to as "calcined". Nickel impregnated LST (Ni/LST) was prepared by wet impregnation of the as calcined LST perovskite with an aqueous solution of $\mathrm{Ni}\left(\mathrm{NO}_{3}\right)_{2} \cdot 6 \mathrm{H}_{2} \mathrm{O}$ (pro analysis, Merck). Drying at $90^{\circ} \mathrm{C}$ overnight was followed by calcination in air at $500^{\circ} \mathrm{C}$ for $2 \mathrm{~h}$. Furthermore, $\mathrm{Y}_{0.08} \mathrm{Zr}_{0.92} \mathrm{O}_{2}$ was impregnated with an aqueous solution of $\mathrm{Ni}\left(\mathrm{NO}_{3}\right)_{2} \cdot 6 \mathrm{H}_{2} \mathrm{O}$ according to the same procedure to obtain $60 \mathrm{wt} \% \mathrm{NiO} / \mathrm{YSZ}$ (calculated $50 \mathrm{vol} \% \mathrm{Ni} / \mathrm{YSZ}$ ) representing a standard solid oxide fuel cell anode material. In order to characterize the redox stability and the catalytic activity towards the water gas shift (WGS) reaction of these materials, aliquots of the powders received reductive and oxidative pretreatments or combinations thereof. If not otherwise stated all pretreatments were conducted at $800^{\circ} \mathrm{C}$. Reduction was carried out in $10 \mathrm{vol} \% \mathrm{H}_{2} / \mathrm{Ar}$, whereas oxidation was conducted in synthetic air $\left(20 \mathrm{vol} \% \mathrm{O}_{2} / \mathrm{N}_{2}\right)$ in a tubular quartz reactor.

The specific surface area (SSA) of the calcined powders was calculated from $\mathrm{N}_{2}$-adsorption isotherms at $-196^{\circ} \mathrm{C}$ according to the Brunauer-Emmet-Teller (BET) model. Adsorption data was acquired using a Quantachrome Autosorb I instrument. Prior to SSA determination the samples were treated under vacuum at $300^{\circ} \mathrm{C}$ for $2 \mathrm{~h}$.

The phase composition and crystal structure of calcined, reduced $\left(10 \mathrm{vol} \% \mathrm{H}_{2}, 800^{\circ} \mathrm{C}, 15 \mathrm{~h}\right)$ and reoxidised powders $\left(20\right.$ vol\% $\left.\mathrm{O}_{2}, 800^{\circ} \mathrm{C}, 2 \mathrm{~h}\right)$ were analyzed by ex situ powder X-ray diffraction (XRD) using a Bruker D8 Advance diffractometer equipped with Ni-filtered Cu radiation, variable slits and an energy sensitive line detector (LynxEye). Diffractograms were collected between $15^{\circ}-80^{\circ} 2 \theta$ with an acquisition time of $4 \mathrm{~s}$ and a step size of $\Delta 2 \theta=0.03^{\circ}$. 
Temperature programmed reduction (TPR) experiments were conducted using a bench top TPDRO1100 (ThermoElectron) instrument equipped with mass flow controllers and a thermal conductivity detector. The samples $(100 \mathrm{mg})$ were loaded into the quartz reactor tube and heated to $500^{\circ} \mathrm{C}$ under constant flow of $20 \mathrm{vol} \% \mathrm{O}_{2}$ before cooling to room temperature. TPRs were recorded in $10 \mathrm{vol} \%$ $\mathrm{H}_{2} / \mathrm{Ar}\left(20 \mathrm{mLmin}^{-1}\right.$ at STP $)$ and at a heating rate of $5^{\circ} \mathrm{Cmin}^{-1}$. The reoxidation temperature at which $\mathrm{Ni}$ is reversibly reincorporated into the perovskite lattice was estimated by TPR redox experiments. A TPR profile was recorded on the calcined sample up to $800^{\circ} \mathrm{C}$ followed by isothermal reduction for $1 \mathrm{~h}$ at the same temperature. The sample was then cooled in Ar to room temperature $\left(25^{\circ} \mathrm{C}\right)$ before reoxidation at $700^{\circ} \mathrm{C}$ in $20 \mathrm{vol} \% \mathrm{O}_{2} / \mathrm{N}_{2}$ for $2 \mathrm{~h}$. The sample was again cooled in Ar to $25^{\circ} \mathrm{C}$ before starting the second TPR on the now reoxidised material. Such TPR-reduction-reoxidation-TPR cycles were repeated five times with increasing reoxidation temperature $\left(700^{\circ} \mathrm{C}, 750^{\circ} \mathrm{C}, 800^{\circ} \mathrm{C}, 850^{\circ} \mathrm{C}\right.$ and $900^{\circ} \mathrm{C}$ ). The heating rate during reoxidation and cooling after all experiments was $10^{\circ} \mathrm{Cmin}^{-1}$.

Nickel K-edge $(8.333 \mathrm{keV}) \mathrm{X}$-ray absorption spectra were acquired ex situ on pelletized samples in fluorescence mode at the X10DA (SuperXAS) beamline of the Swiss Synchrotron Light Source (SLS, Villigen, Switzerland) using a 5 element SD detector. The required X-ray energies were scanned using a Si(111) monochromator. The Demeter software package (version 0.9.24) ${ }^{41}$ was used to reduce and model all data. The radial distribution function $(\mathrm{R})$ was obtained by Fourier transforming $\mathrm{k}^{3}$-weighted k-functions typically in the range of $3.0-12.0 \AA^{-1}$ using a Hanning window function. Fitting of bond distances was generally performed in the range of 1.0-4.0 $\AA$. NiO (99.99\% trace metals basis, Sigma) and $\mathrm{Ni}$ foil references were measured in transmission mode using ionization chamber detectors.

Linear combination fitting (LCF) of X-ray absorption near edge structure (XANES) spectra was performed in the spectral range $-20 \mathrm{eV}<\mathrm{E}_{0}<30 \mathrm{eV}$ around the absorption edge to quantify the fraction of each Ni species present in the samples. Reference compounds for each fit included Ni-foil, 
$\mathrm{NiO}$ and calcined $\mathrm{La}_{0.3} \mathrm{Sr}_{0.55} \mathrm{Ti}_{0.95} \mathrm{Ni}_{0.05} \mathrm{O}_{3 \pm \delta}$ representing $\mathrm{Ni}^{\mathrm{n}+}{ }_{\text {oct }}(\mathrm{n}>2)$ in the perovskite coordination environment.

X-ray fluorescence was collected ex situ on pretreated and pelletized samples at the Phoenix beamline at SLS. A 4-element Si drift diode array was used to collect fluorescent radiation at am incident X-ray energy of $2600 \mathrm{eV}$.

Changes in the microstructure of the samples as a result of repeated redox cycles were studied using scanning electron microscopy (field emission SEM, Zeiss ULTRA 55). The samples were analyzed using a $5 \mathrm{keV}$ electron beam and the in-lens secondary electron detector at a working distance of 1.8 $\mathrm{mm}$. Typical magnifications in the range of 50’000-100,000 allowed the analysis of Ni particles of ca. $5-10 \mathrm{~nm}$.

Scanning transmission electron microscopy (STEM) images were acquired using an analytical TEM (FEI Talos F200X) equipped with a Super-X EDX system (windowless) and a high angle annular dark field (HAADF) detector. The accelerating voltage was set to $200 \mathrm{kV}$. EDX maps (512 x 512 pixels) were acquired with a resolution of $7 \mathrm{~nm}$.

Catalytic activity tests towards the water gas shift reaction (WGS) were carried out with a homemade test setup in a quartz reactor of plug flow geometry $(6 \mathrm{~mm}$ ID). Mass flow controllers were used to dose the reactant gases and a thermocouple placed in the middle of the catalyst bed was used to determine catalyst bed temperature. To avoid back pressure all calcined powders were pelletized (4 $\mathrm{MPa})$, crushed in an agate mortar and sieved to $100-150 \mu \mathrm{m}$ before use. The catalyst (100 mg) was diluted with cordierite powder $(100 \mathrm{mg}, 75-100 \mu \mathrm{m})$ to achieve a thoroughly mixed catalyst bed of 10 $\mathrm{mm}$ in length. The reactant gas containing $15 \mathrm{vol} \% \mathrm{CO}, 15 \mathrm{vol} \% \mathrm{H}_{2} \mathrm{O}, 7.5 \mathrm{vol} \% \mathrm{H}_{2}$ (rest Ar) was fed at a total flow rate of $50 \mathrm{mLmin}^{-1}$ at STP resulting in a weight hourly space velocity (WHGS) of 30,000 $\mathrm{mLg}^{-1} \mathrm{~h}^{-1}$. Catalytic tests were conducted on pre-reduced samples $\left(20 \mathrm{vol} \% \mathrm{H}_{2}, 800^{\circ} \mathrm{C}, 1 \mathrm{~h}\right)$. The 
experiment was started at $800^{\circ} \mathrm{C}$ under reaction conditions after the catalyst was left to equilibrate for $10 \mathrm{~min}$ before cooling to $300^{\circ} \mathrm{C}$ at $5{ }^{\circ} \mathrm{Cmin}^{-1}$. All stainless steel gas lines were heated to $120^{\circ} \mathrm{C}$ to avoid condensation. Compositional analysis of the exhaust gas was performed using a quadrupole mass spectrometer (Pfeiffer OmniStar GSD 320) equipped with a heated stainless steel capillary. CO conversion $\left(\mathrm{C}_{\mathrm{CO}}\right)$ was determined according to eq. 1

$$
C_{C O}[\%]=100 \cdot \frac{[\mathrm{CO}]_{\text {in }}-[\mathrm{CO}]_{\text {out }}}{[\mathrm{CO}]_{\text {in }}}
$$

where $[\mathrm{CO}]_{\text {in }}$ and $[\mathrm{CO}]_{\text {out }}$ are the initial and final $\mathrm{CO}$ concentrations, respectively.

Equilibrium conversions were calculated from the following expression (eq. 2) for the WGS equilibrium constant $\mathrm{K}_{\mathrm{eq}}{ }^{42}$

$$
\log \mathrm{K}_{\mathrm{eq}}=\frac{5693.5}{\mathrm{~T}}+1.077 \ln \mathrm{T}+5.44 * 10^{-4} \mathrm{~T}-1.125 * 10^{-7} \mathrm{~T}^{2}-\left(\frac{49170}{\mathrm{~T}^{2}}\right)-13.148
$$

and the relationship

$$
\mathrm{K}_{\mathrm{eq}} \cong \frac{\left[\mathrm{CO}_{2}\right] *\left[\mathrm{H}_{2}\right]}{[\mathrm{CO}] *\left[\mathrm{H}_{2} \mathrm{O}\right]}
$$

where $\left[\mathrm{CO}_{2}\right],\left[\mathrm{H}_{2}\right],[\mathrm{CO}]$ and $\left[\mathrm{H}_{2} \mathrm{O}\right]$ are the concentrations of the corresponding gases at equilibrium.

The effect of sulfur poisoning was assessed on pre-reduced LSTN $\left(20 \mathrm{vol} \% \mathrm{H}_{2} / \mathrm{Ar}, 800^{\circ} \mathrm{C}, 1 \mathrm{~h}\right)$ after eight redox cycles. The material was subjected to the water gas shift reaction mixture additionally containing $50 \mathrm{ppm} \mathrm{H}_{2} \mathrm{~S}$ at $800^{\circ} \mathrm{C}$ for $2 \mathrm{~h}$ before cooling in Ar. The water gas shift activity of the poisoned catalyst was then obtained in identical tests to those on the non-poisoned material. Catalyst regeneration was conducted through two consecutive redox cycles at $800^{\circ} \mathrm{C}(1 \mathrm{~h}$ reduction followed by $2 \mathrm{~h}$ reoxidation). 
The preliminary tests of full solid oxide cells based on pure LSTN anodes exhibited a high polarization resistance due to the low ionic conductivity of the LSTN anode layer because of the short length of triple phase boundaries at the interphase with the electrolyte. ${ }^{43-44}$ Hence, electrochemical tests were conducted on composite electrodes with high LSTN content in a full cell design. LSTN powders were mixed with ionically conductive gadolinium cerium oxide $\left(\mathrm{Ce}_{0.9} \mathrm{Gd}_{0.1} \mathrm{O}_{2}, \mathrm{CGO}\right)$, dispersed in terpene alcohol (mixture of isomers, anhydrous, Fluka) and homogenized by planetary milling as described elsewhere. ${ }^{45}$ Screen-printable inks with 60 vol\% LSTN and 40 vol\% CGO and $\mathrm{La}_{0.2} \mathrm{Sr}_{0.8} \mathrm{MnO}_{3^{-}}$ $\mathrm{Y}_{0.15} \mathrm{Zr}_{0.85} \mathrm{O}_{2}$ (LSM-YSZ) cathodes (50:50 vol\%) were printed onto sintered $\mathrm{Sc}_{0.12} \mathrm{Zr}_{0.88} \mathrm{O}_{2}$ electrolyte $\left(120 \mu \mathrm{m}\right.$ thickness, non-reactive with titanates) and both electrodes were co-fired at $1150^{\circ} \mathrm{C}$ for $3 \mathrm{~h} .{ }^{46}$ Nickel-free LST was printed on top of the active layer of the electrode for current collection and contacted to measurement electrodes by $\mathrm{Au}$ and Ni meshes. The prepared cells (active electrode area $=$ $1.44 \mathrm{~cm}^{2}$ ) were inserted into the test setup, sealed with a ceramic gasket (Insufliz) and connected to the measuring terminal (Zahner IM6ex). Electrochemical impedance spectroscopy (EIS) and voltammetry were used for characterization. Cells were heated in oxidizing atmosphere at a rate of $3{ }^{\circ} \mathrm{Cmin}^{-1}$ and anodes reduced and operated in pure hydrogen (PanGas, 5.0) at a gas flow of $200 \mathrm{mLmin}^{-1}$ at STP. Air was supplied to the cathode with a flow rate of $450 \mathrm{mLmin}^{-1}$ at STP. Cell temperature was measured via the thermoelectric potential of an S-type thermocouple located close to the cell. Anode reoxidation was conducted by $30 \mathrm{~min}$ fuel cut-offs at the working temperature of $850^{\circ} \mathrm{C}$ under open circuit voltage $(\mathrm{OCV})$. The cell was operated in electrolysis mode $(-2.0 \mathrm{~V})$ twice for $2 \mathrm{~min}$ and once for 2 min under current overload $\left(2.0 \mathrm{Acm}^{-2}\right)$ to monitor the effects of these treatments on area specific resistance. Impedance spectra were collected in the frequency range between $0.01 \mathrm{~Hz}$ and $1 \mathrm{MHz}$ in galvanostatic mode, both under OCV and under polarization when drawing $200 \mathrm{mAcm}^{-2}$. Changes in the impedance spectra were analyzed by Analysis of Differences in Impedance Spectra (ADIS), which shows frequency dependent changes of impedance upon variation of operating conditions. ${ }^{47}$ 
The differential method (ADIS) is based on the analysis of real parts of impedance spectra:

$$
\Delta \delta Z=\left|\left(\frac{\partial Z_{\text {Real }}^{P 1}}{\partial \log f}\right)-\left(\frac{\partial Z_{\text {Real }}^{P 2}}{\partial \log f}\right)\right|
$$

where $\delta Z_{\text {Real }}^{P 1}$ and $\delta Z_{\text {Real }}^{P 2}$ are differentials of the real impedance part upon the change of one experimental parameter (P1, P2 represent states before and after redox cycling).

\section{Discussion}

\subsection{Nickel reduction and segregation}

The individual powder grains of calcined $\mathrm{La}_{0.3} \mathrm{Sr}_{0.55} \mathrm{Ti}_{0.95} \mathrm{Ni}_{0.05} \mathrm{O}_{3-\delta}$ (LSTN) were composed of individual crystallites forming a porous network as depicted in the scanning electron microscopy (SEM) image in Figure 1-a. All calcined perovskite-type oxide powders showed excellent phase purity and high crystallinity (Figure S1). Table S1 summarizes general powder characterization results including specific surface areas (SSA) and the analysis of X-ray diffraction (XRD) patterns. All sample abbreviations used throughout the discussion are also given in Table S1. The perovskite samples LSTN and LST contained a single cubic perovskite phase (Pm-3m), which was observed and reported also for undoped and stoichiometric $\mathrm{SrTiO}_{3 \pm \delta .}{ }^{48}$ No indication of secondary phases (NiO) could be found by SEM on impregnated $\mathrm{Ni} / \mathrm{La}_{0.3} \mathrm{Sr}_{0.55} \mathrm{TiO}_{3-\delta}(\mathrm{Ni} / \mathrm{LST}$, Figure 1-b) even though NiO reflections (i.e. (200) at $2 \theta \approx 43.3^{\circ}$ ) could be observed by XRD. Reduction of both LSTN and Ni/LST at $800^{\circ} \mathrm{C}$ resulted in the display of metallic Ni particles on the surface of the materials. This is less surprising in the case of impregnated $\mathrm{Ni} / \mathrm{LST}$ where $\mathrm{NiO}$ was simply reduced to $\mathrm{Ni}^{0}$ on the support surface. In LSTN however, formation of the observed particles must have occurred from reduction of Ni from the bulk of the material and segregation to the crystallite surface. The segregation of $\mathrm{Ni}$ and the formation of $\mathrm{Ni}$ 
particles on LSTN can be observed in the STEM image of the sample reduced at $800^{\circ} \mathrm{C} / 15 \mathrm{~h}$ (Figure 1c), after which few small particles in the size range of $10-30 \mathrm{~nm}$ were visible. These features overlap with the areas of increased Ni concentrations obtained from the elemental mapping of Ni (STEM EDX, Figure 1-d). All other elements remained uniformly distributed across the particles and likely remained inside the metal oxide crystallites. Therefore, we consider that segregation of other elements than Ni did not occur.

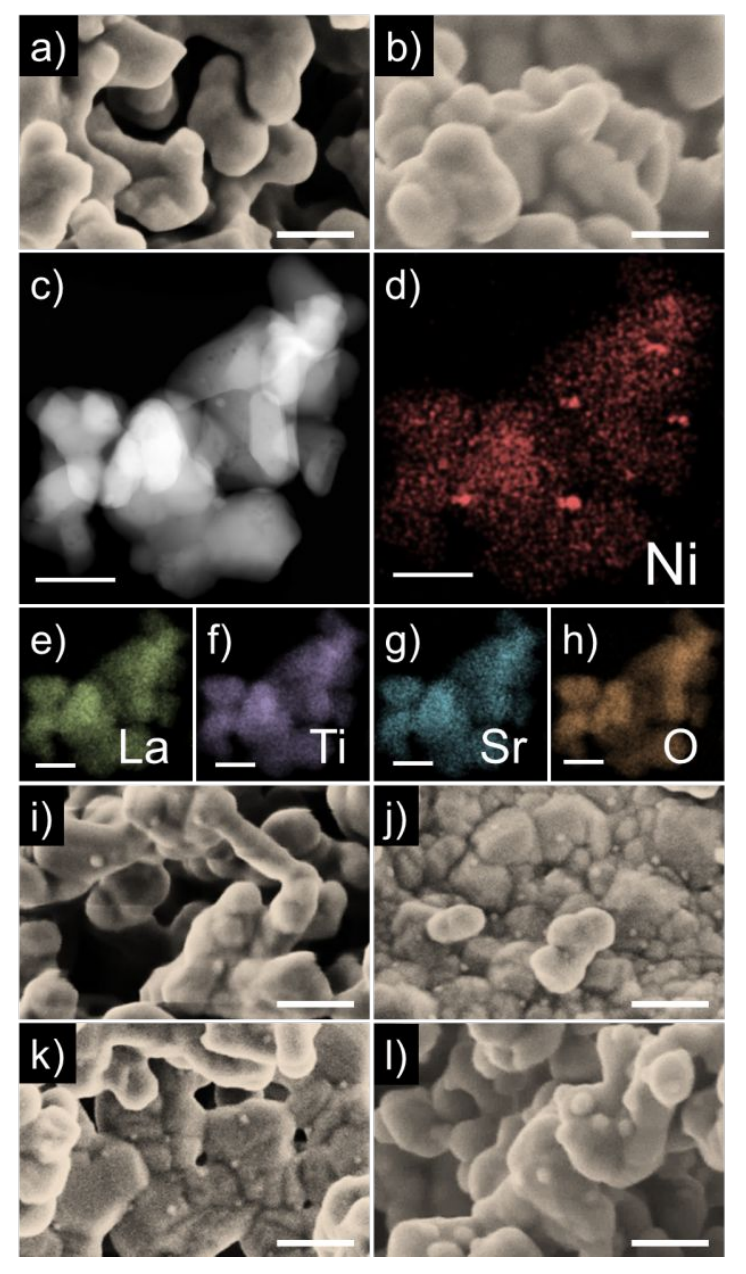

Figure 1. SEM images of a) LSTN and b) Ni/LST after calcination. c) High angle annular dark field TEM image of reduced LSTN $\left(800^{\circ} \mathrm{C}, 10 \mathrm{vol} \% \mathrm{H}_{2}, 15 \mathrm{~h}\right.$ ); Elemental maps (STEM-EDX) of same sample region displaying $\mathrm{Ni}$, (d) $\mathrm{La}$, (e) $\mathrm{Ti}$, (f) $\mathrm{Sr}$ (g) and $\mathrm{O}$ concentrations (h). Scale bars represent $200 \mathrm{~nm}$. SEM images of (i) LSTN and (j) Ni/LST after single reduction $\left(800^{\circ} \mathrm{C}, 10 \mathrm{vol} \% \mathrm{H}_{2}, 1 \mathrm{~h}\right)$ as well as reduced after eight redox cycles (k) and (1), respectively. Scale bars on SEM images represent $100 \mathrm{~nm}$. 


\subsection{Self-regenerating property}

Inherent material redox stability is decisive for application in a regenerable SOFC anode. Since the intended regeneration from sulfur poisoning involves anode redox cycling, additional catalyst deactivation due to Ni particle growth over the number of redox cycles may strongly limit its functionality. Figure 1 depicts a series of SEM images of LSTN (Figure 1-i and Figure 1-k) and Ni/LST (Figure 1-j and Figure 1-1) after a single reduction step at $800^{\circ} \mathrm{C}$ and reduced after eight redox cycles. Nickel particles are visible on all images. However, in the case of LSTN the size of these particles did not change significantly over eight redox cycles, whereas clear indications of Ni particle growth can be seen in the case of Ni/LST. After a single reduction step the material displayed numerous small Ni particles (mean size ca. $10 \mathrm{~nm}$ ), whereas after eight redox cycles most particles had grown to $20-40 \mathrm{~nm}$ in size. Therefore, particle growth over redox cycles was indeed an issue on the impregnated Ni/LST, whereas the self-regenerating property of LSTN stabilized Ni particle size over the course of the treatment. 

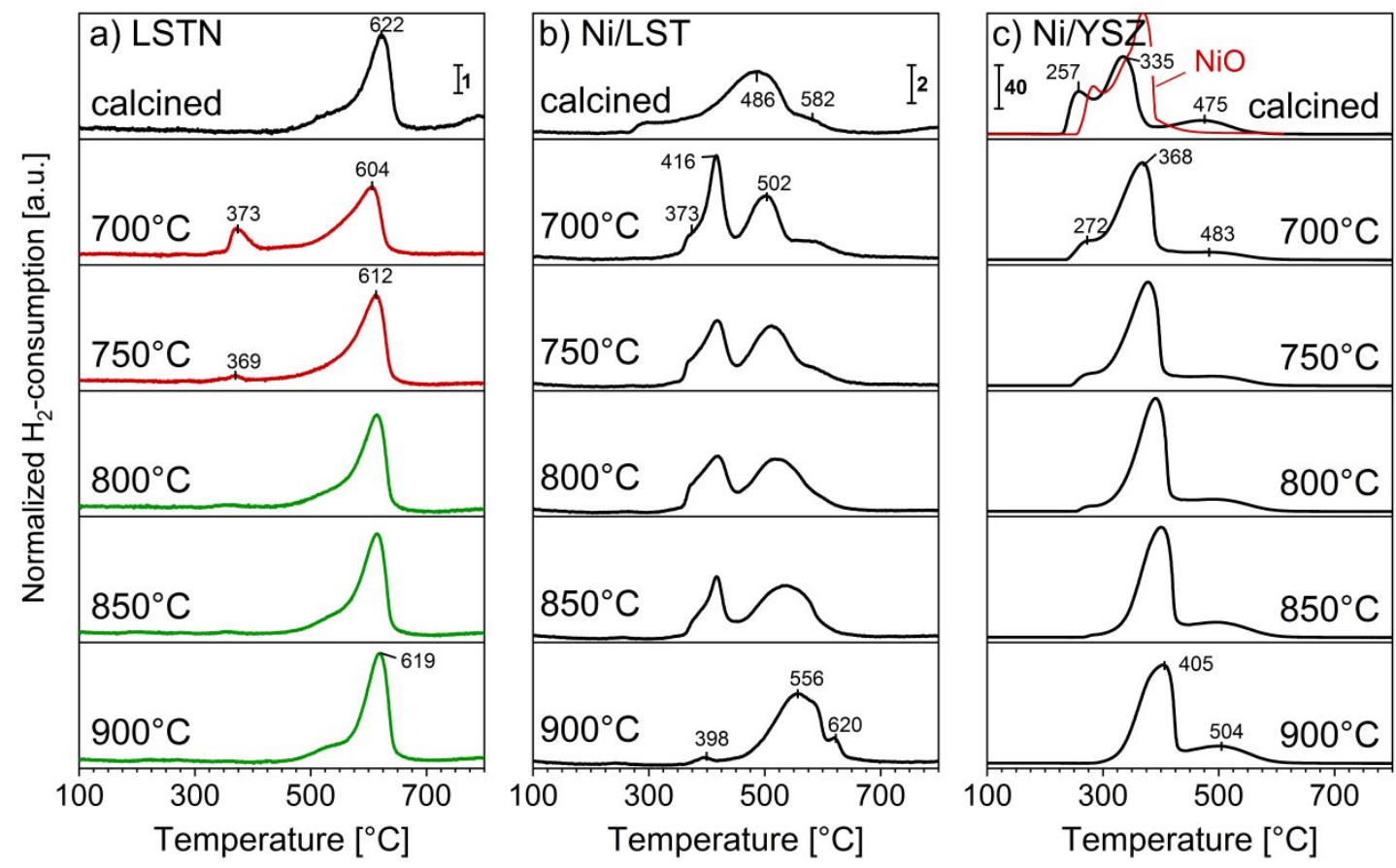

Figure 2. Temperature programmed reduction-reoxidation cycles for (a) LSTN, (b) Ni/LST and (c) $\mathrm{Ni} / Y S Z$. Hydrogen consumption values were normalized by the number of moles of sample used. Reoxidised samples were subjected to pre-reduction in $10 \mathrm{vol} \% \mathrm{H}_{2}$ at $800^{\circ} \mathrm{C}$ for $1 \mathrm{~h}$ before reoxidation at the given temperature $\left(20 \mathrm{vol} \% \mathrm{O}_{2}, 2 \mathrm{~h}\right)$. Reduction profile of $\mathrm{NiO}$ reference is depicted in top row of c).

Metal segregation from and reincorporation back into perovskite-type oxide lattices is a temperature dependent process. ${ }^{49}$ It is therefore of great interest for practical application to determine the reoxidation temperature at which $\mathrm{Ni}$ can be completely reincorporated into the perovskite lattice. This was achieved using a strategy previously applied to investigate $\mathrm{Ni}$ reincorporation into $\mathrm{LaFe}_{1-\mathrm{x}} \mathrm{Ni}_{\mathrm{x}} \mathrm{O}_{3 \pm \delta}$ host lattices. ${ }^{38}$ Figure 2 shows the results of $\mathrm{H}_{2}$-temperature programmed reduction (TPR) reoxidation cycles on the three Ni catalysts. Similarities in the reduction profiles of calcined Ni/LST (Figure 2-b) and Ni/YSZ (Figure 2-c) were expected since XRD analysis (summarized in Table S1) already indicated the presence of a $\mathrm{NiO}$ phase dispersed on both materials. Reduction started below $250^{\circ} \mathrm{C}$ and appeared to be complete at $630^{\circ} \mathrm{C}$. Reduction of calcined Ni/LST peaked at $486^{\circ} \mathrm{C}$, whereas 
the highest hydrogen consumption of $\mathrm{Ni} / \mathrm{YSZ}$ occurred at $335^{\circ} \mathrm{C}$. In general, the shape and temperature range of the reduction profile of $\mathrm{Ni} / \mathrm{YSZ}$ was very similar to that obtained on pure $\mathrm{NiO}$ powder, which showed maximum rate of reduction at $370^{\circ} \mathrm{C}$ (Figure 2-c). In marked contrast, $\mathrm{H}_{2}$-consumption during the TPR of calcined LSTN started at $450^{\circ} \mathrm{C}$ and peaked at $622^{\circ} \mathrm{C}$. The evident differences in the reduction profiles of these materials are due to the different state of $\mathrm{Ni}$ - as determined by X-ray absorption spectroscopy (XAS, vide infra in Figure 4) - and distinguish NiO from incorporated Ni species $\left(\mathrm{Ni}^{\mathrm{n}+}{ }_{\text {oct }}\right)$. Reduction profiles can therefore be used to determine the state of $\mathrm{Ni}$ and to estimate the oxidation temperature necessary to reincorporate $\mathrm{Ni}$ into the perovskite lattice.

Figure 2 also shows a series of TPR profiles for each sample after pre-reduction $\left(800^{\circ} \mathrm{C}, 10\right.$ vol\% $\left.\mathrm{H}_{2} / \mathrm{Ar}, 1 \mathrm{~h}\right)$ and subsequent reoxidation $\left(\mathrm{T}=700,750,800,850\right.$ and $\left.900^{\circ} \mathrm{C}, 20 \mathrm{vol} \% \mathrm{O}_{2} / \mathrm{N}_{2}, 2 \mathrm{~h}\right)$. In the case of LSTN, whenever the reoxidation temperature was not sufficient to reincorporate all Ni into the lattice during the reoxidation a distinctive reduction peak of $\mathrm{NiO}$ appeared at ca. $370^{\circ} \mathrm{C}$ in the subsequent TPR. After reoxidation at $\mathrm{T} \geq 800^{\circ} \mathrm{C}$ this $\mathrm{NiO}$ feature disappeared, which indicated full $\mathrm{Ni}$ reincorporation into the LSTN lattice.

$\mathrm{Ni} / \mathrm{LST}$ and Ni/YSZ also showed changes in the reduction profiles from the calcined to the reoxidised materials, which can be attributed predominantly to morphological changes of the NiO phase. ${ }^{50}$ The higher reduction temperature of $\mathrm{NiO} / \mathrm{LST}$ compared to $\mathrm{Ni} / \mathrm{YSZ}$ was attributed to the close contact between the small amount of $\mathrm{Ni}$ and the oxygen providing perovskite surface in Ni/LST. In this case, LST might have acted as an oxygen source to prevent $\mathrm{NiO}$ reduction at low temperatures. Nevertheless, from the evolution of the reduction profile shape of the impregnated samples (Ni/LST and $\mathrm{Ni} / \mathrm{YSZ}$ ) it can be assumed that $\mathrm{Ni}$ was always present as $\mathrm{NiO}$ species after each reoxidation cycle. Similar TPR redox experiments involving multiple redox cycles at a constant reoxidation temperature of $800^{\circ} \mathrm{C}$ were also conducted (Figure S2). This temperature is typical of SOFC operation ${ }^{51}$ as well as the temperature at which $\mathrm{Ni}$ was found to reincorporate into the perovskite lattice in LSTN. The 
reduction profile of LSTN showed complete reversibility over all cycles and the temperature range of $\mathrm{H}_{2}$-consumption remained between $450^{\circ} \mathrm{C}$ and $650^{\circ} \mathrm{C}$ with a maximum at $614-627^{\circ} \mathrm{C}$. Reversible reduction profiles were also found for Ni-free LST pointing to the intrinsic redox stability of the host perovskite structure. The reduction feature observed for LST was assigned to the loss of oxygen and partial reduction of $\mathrm{Ti}^{4+}$ to $\mathrm{Ti}^{3+}$. The two impregnated samples $\mathrm{Ni} / \mathrm{LST}$ and $\mathrm{Ni} / \mathrm{YSZ}$ appeared to change significantly after the first reoxidation. Changes were likely due to the low initial calcination temperatures of $500^{\circ} \mathrm{C}$ after impregnation with the $\mathrm{Ni}$ precursor compared to the high reoxidation temperature of $800^{\circ} \mathrm{C}$ used during the experiment. After the first high temperature reoxidation all samples maintained their reduction profiles in the next redox cycles. Slight peak narrowing was observed over the course of the redox cycles for the two impregnated samples, which has previously been attributed to increased metal oxide crystallinity and can also be taken as an indication of $\mathrm{NiO}$ particle growth, hence degeneration of the potential anode material..$^{52}$ 
Figure 3. X-ray diffraction patterns of LST (black) LSTN (blue) and Ni/LST (red) in the angular range of $42.0^{\circ} \leq 2 \theta \leq 46.0^{\circ}$ in their calcined state, after reduction $\left(800^{\circ} \mathrm{C}, 10 \mathrm{vol} \% \mathrm{H}_{2}, 1 \mathrm{~h}\right)$, after reoxidation $\left(800^{\circ} \mathrm{C}, 20 \mathrm{vol} \% \mathrm{O}_{2}, 2 \mathrm{~h}\right)$ and reduced after eight redox cycles. The position of the $\mathrm{NiO}(200)$ reflection at $43.299^{\circ}$ and the $\mathrm{Ni}$ (111) reflection at $44.473^{\circ}$ are indicated with dashed and dotted lines, respectively.

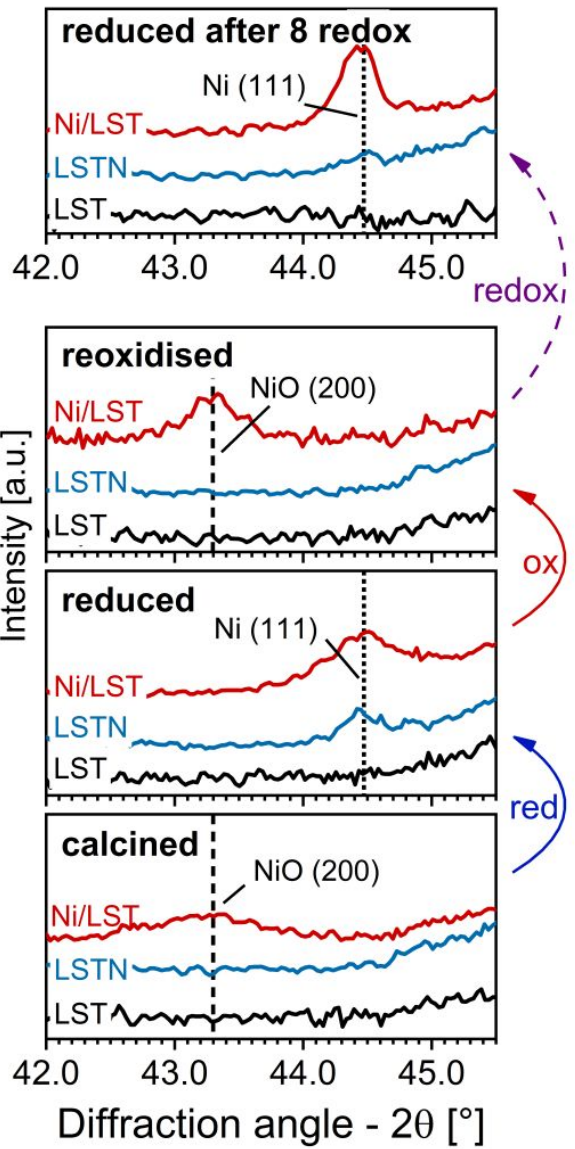

The beneficial consequences of exploiting the smart material concept, ${ }^{30}$ i.e. the absence of Ni particle growth on LSTN and the evidence of particle growth on impregnated Ni/LST, can also be visualized by XRD. Figure 3 shows the angular range in $2 \theta$ between $42-45.5^{\circ}$ (including the main (200) reflection of $\mathrm{NiO}$ at $43.3^{\circ}$ and the (111) reflection of $\mathrm{Ni}$ at $44.5^{\circ}$ ) of $\mathrm{LSTN}, \mathrm{Ni} / \mathrm{LST}$ as well as plain LST for reference purposes over a similar series of redox cycles. Only a broad NiO reflection was 
observed on calcined $\mathrm{Ni} / \mathrm{LST}$, whereas no $\mathrm{NiO}$ reflection was present in LSTN and obviously LST (Figure 3-a). After reduction at $800^{\circ} \mathrm{C}$ the $\mathrm{Ni}$ (111) reflection appeared in both LSTN and Ni/LST (Figure 3-b). This reflection disappeared on LSTN after reoxidation at $800^{\circ} \mathrm{C}$, whereas it changed into a strong $\mathrm{NiO}$ reflection in the case of Ni/LST. This indicates complete Ni reincorporation in the case of LSTN and the absence of this process in Ni/LST (Figure 3-c). However, XRD may not be sensitive enough to detect the presence of small and/or low concentrations of secondary phase crystallites. Nevertheless, after eight consecutive redox cycles (Figure 3-d) the Ni (111) reflection had significantly narrowed in the XRD of Ni/LST compared to the reflection after the initial reduction (Figure 3-b), thus indicating the undesired process of Ni crystallite growth. No significant peak narrowing was observed in the case of LSTN.

The fact that $\mathrm{Ni}$ was changing oxidation states between that of $\mathrm{NiO}$ and of $\mathrm{Ni}^{0}$ over the course of the redox cycle in the case of $\mathrm{Ni} / \mathrm{LST}$, whereas it was changing reversibly between $\mathrm{Ni}^{\mathrm{n}+}{ }_{\text {oct }}$ inside the perovskite and $\mathrm{Ni}^{0}$ in the case of LSTN, is reinforced by the Ni K-edge X-ray absorption near edge spectra (XANES) of LSTN (Figure 4-a) and Ni/LST (Figure 4-b). The spectrum of the reference Nifoil showed a clear edge at $8333 \mathrm{eV}$ and no whiteline was visible, which is typical for metallic samples. The absorption edge of $\mathrm{NiO}$ was shifted towards higher energies $(8340 \mathrm{eV})$ due to the higher oxidation state of $\mathrm{Ni}^{2+}$ and the spectrum included a clear single peak of the whiteline. The spectrum also contained a local minimum at $8361 \mathrm{eV}$, which can be used as a fingerprint feature of $\mathrm{NiO}$ in the Ni Kedge XANES region. The spectrum of calcined LSTN showed a more complex and intense witheline including a shoulder at $8352 \mathrm{eV}$ and no feature at $8361 \mathrm{eV}$. 


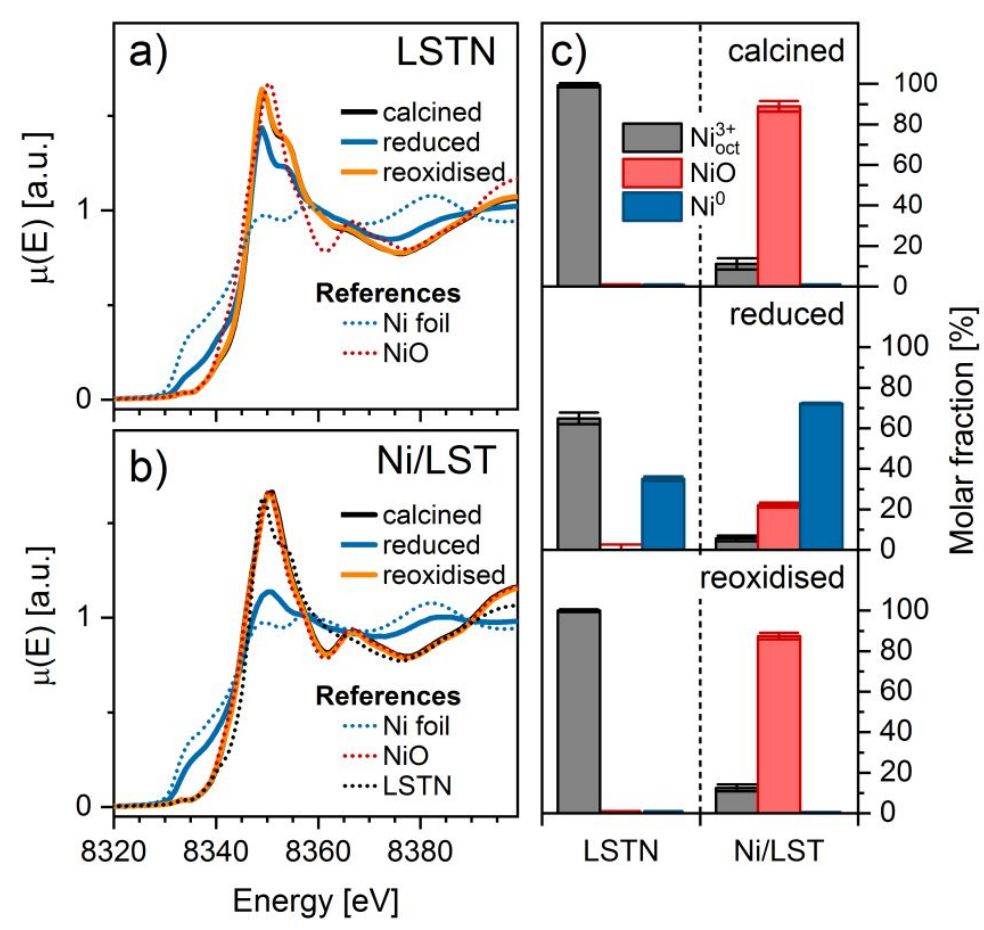

Figure 4. Normalized Ni K-edge (8333 eV) X-ray absorption near edge structure (XANES) data obtained for (a) LSTN and (b) Ni/LST calcined, reduced $\left(10 \mathrm{vol} \% \mathrm{H}_{2}, 800^{\circ} \mathrm{C}, 1 \mathrm{~h}\right)$ and reoxidised $\left(20 \mathrm{vol} \% \mathrm{O}_{2}, 800^{\circ} \mathrm{C}, 2 \mathrm{~h}\right)$. The spectra of $\mathrm{Ni}$-foil and $\mathrm{NiO}$ reference materials are also shown. c) $\mathrm{Ni}$ speciation obtained from linear combination fitting of XANES data on LSTN and Ni/LST after calcination, after reduction and after reoxidation.

The spectra obtained after calcination and reoxidation completely overlapped in both materials. After reduction at $800^{\circ} \mathrm{C}$, the spectra exhibited an intensified feature at $8335 \mathrm{eV}$ and a whiteline of decreased intensity, thus resembling a linear combination of the spectra of the calcined material and the Ni-foil reference. Linear combination analysis was performed to determine the contribution of each Ni species $\left(\mathrm{NiO}, \mathrm{Ni}^{0}\right.$ and $\left.\mathrm{Ni}^{\mathrm{n}+}{ }_{\text {oct }}\right)$ to the spectra of the reduced materials. The spectrum of LSTN was taken as representative of $\mathrm{Ni}^{\mathrm{n}+}$ oct Results are presented in Figure 4-c and the full fits and residuals are provided in Figure S3. Nickel was predominantly present as $\mathrm{NiO}$ on Ni/LST ( $>85 \%)$. The coordination of the remaining $\mathrm{Ni}$ resembled the one of $\mathrm{Ni}^{\mathrm{n}+}{ }_{\text {oct }}$, which could indicate possible $\mathrm{Ni}$ incorporation into LST. 
After reduction at $800^{\circ} \mathrm{C}, 35 \%$ of the overall $\mathrm{Ni}$ was reduced to metallic $\mathrm{Ni}$ in the case of LSTN, whereas the extent of reduction was much higher $(70 \%)$ for impregnated Ni/LST. This behavior is explained with the fact that Ni in LSTN is evenly distributed within the bulk of the perovskite lattice and is not easily accessible to the reducing environment. In the case of Ni/LST, Ni is directly exposed to the gas environment. In both cases reoxidation restored the original Ni species. The observation of the reversible $\mathrm{Ni}$ segregation in the case of LSTN validates all observations and interpretations obtained by electron microscopy, XRD and TPR.

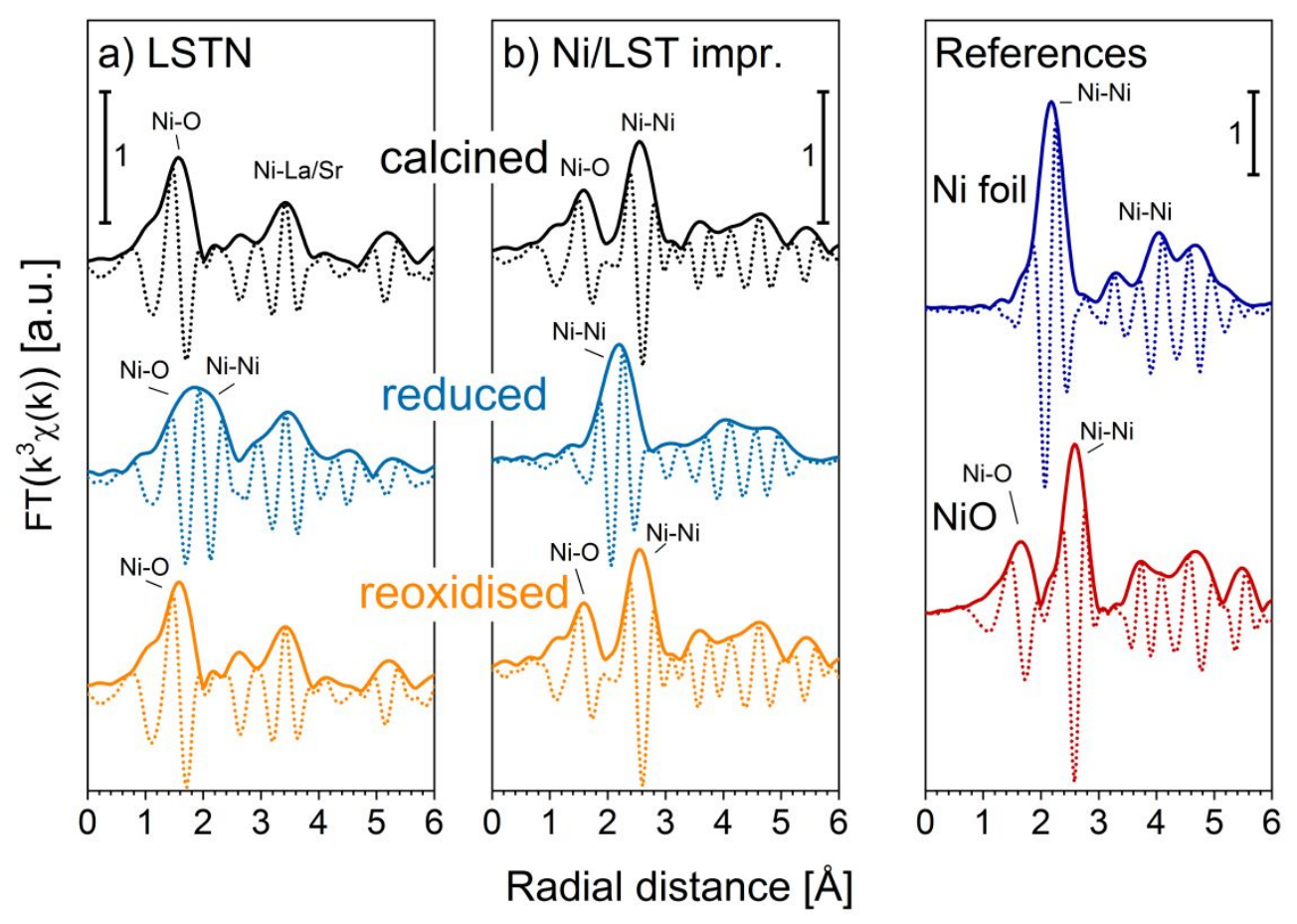

Figure 5. Fourier transformed $\mathrm{k}^{3}$-weighted Ni K-edge EXAFS data obtained for (a) LSTN and (b) $\mathrm{Ni} /$ LST calcined, after reduction $\left(800^{\circ} \mathrm{C}, 10 \mathrm{vol} \% \mathrm{H}_{2}, 1 \mathrm{~h}\right)$ and reoxidation $\left(800^{\circ} \mathrm{C}, 20 \mathrm{vol} \% \mathrm{O}_{2}, 2 \mathrm{~h}\right)$. Features are labelled according to their underlying scattering paths. Reference compounds are shown for comparison.

Extended X-ray absorption fine structure (EXAFS) analysis and fitting consolidate our claim of reversible Ni segregation from LSTN. The radial distribution function obtained by Fourier 
transformation of the $\mathrm{k}^{3}$-weighted EXAFS is shown in Figure 5. The signals of all reference materials displayed substantial differences (Figure 5-a). Nickel metal exhibits a characteristic first peak at $2.48 \AA$ corresponding to the first Ni coordination shell, which consists of twelve neighboring Ni atoms in the fec crystal structure. The first coordination shell of $\mathrm{Ni}$ in $\mathrm{NiO}$ contains six oxygen anions at a distance of $2.07 \AA$ followed by a Ni coordination shell at $2.95 \AA$. In LSTN (Figure 5-b) the first oxygen coordination shell was found at a mean distance of $1.95 \AA$, which is shorter than in $\mathrm{NiO}$ due to the higher oxidation state of Ni in LSTN. The second coordination shell at around $3.3 \AA$ is provided by the A-site cations $\left(\mathrm{La}^{3+}\right.$ and $\left.\mathrm{Sr}^{2+}\right)$ while the Ni-Ni feature present in $\mathrm{NiO}$ was absent. The development of the feature at $2.5 \AA$ corresponding to the Ni coordination shell in Ni metal was observed after reduction in both LSTN (Figure 5-a) and Ni/LST (Figure 5-b). Upon reoxidation the original coordination environment of $\mathrm{Ni}$ was completely restored in both samples, as revealed by the similarity of the radial distribution curves of the reoxidised and the calcined states. Similar conclusions can also be drawn directly from the $\mathrm{k}^{3}$-weighted EXAFS functions $\left(\mathrm{k}^{3} \cdot \chi(\mathrm{k})\right.$, Figure $\left.\mathrm{S} 4\right)$ as signature features of each Ni species and coordination state in the samples are clearly visible. The signature features included a distinct triple feature between $5.0 \AA$ and $6.5 \AA^{-1}$ for $\mathrm{Ni}^{\mathrm{n}+}$ oct in LSTN, where the first two peaks were weak and followed by an intense third feature. The range in wavenumbers used for identification of $\mathrm{NiO}$ is somewhat narrower $\left(5.8-6.8 \AA^{-1}\right)$ and included a distinctive double feature, of which the second peak was slightly more pronounced. The complete reversibility of $\mathrm{k}^{3} \cdot \chi(\mathrm{k})$ profiles between calcined and reoxidised LSTN and Ni/LST can therefore already be appreciated prior to Fourier transformation.

\subsection{Redox stability of water gas shift catalyst}

The ability of the anode material to catalyze water gas shift (WGS) is widely regarded to be critical for the efficiency of a SOFC operated on syngas feeds as readily oxidizable $\mathrm{H}_{2}$ fuel is produced. ${ }^{53}$ This is also one of the main reasons for the use of high loadings of metallic $\mathrm{Ni}$ in Ni/oxide cermet anodes 
besides excellent electronic conductivity of metallic Ni. It is clear that the dynamic conditions in the presence of electric current flow through a working SOFC anode cannot be easily replicated by the relatively simple experimental setup used for catalytic tests in plug flow reactors. Nevertheless, such tests provide important information on the intrinsic redox stability of the catalyst.
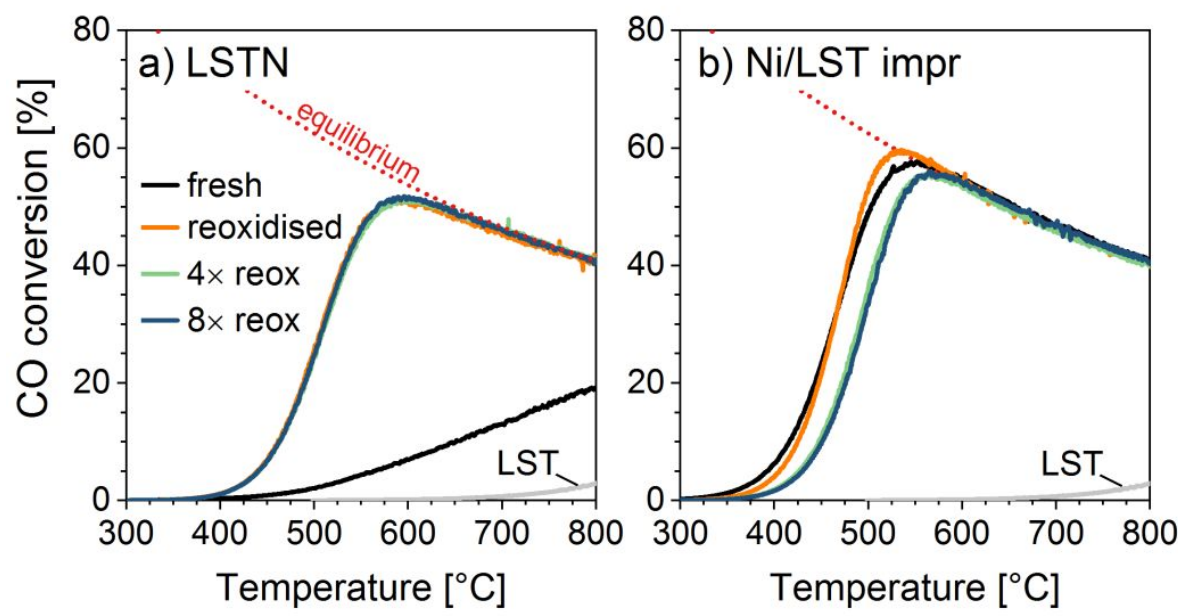

Figure 6. WGS activity profiles of reduced (a) LSTN and (b) Ni/LST over eight redox cycles. Feed gas composition: $15 \mathrm{vol} \% \mathrm{CO}, 15 \mathrm{vol} \% \mathrm{H}_{2} \mathrm{O}, 7.5 \mathrm{vol} \% \mathrm{H}_{2}$, rest Ar; at 30,000 $\mathrm{mLh}^{-1} \mathrm{~g}^{-1}$ (at STP). The calculated theoretical conversion equilibrium is indicated by the dotted red curve.

Figure 6 displays typical CO conversions measured on LSTN (Figure 6-a) and Ni/LST (Figure 6-b) catalysts over eight redox cycles. Pre-reduced LSTN only showed very limited WGS activity and CO conversions did not exceed $20 \%$ even at high temperatures under the conditions used in this test. However, after a single oxidation-reduction cycle its catalytic activity improved significantly and equilibrium conversions were reached. It is assumed that this effect arises from increased amounts of Ni made available on the perovskite surface by high temperature reduction. It is obvious that conversion curves of LSTN after four and after eight redox cycles were identical to the one obtained after the first redox cycle. Comparison of the activity of LSTN and Ni/LST to the negligible conversion obtained for Ni-free LST indicated that the Ni metal surface area generated by reduction bestowed 
catalytic activity to the material (Figure S5). Stable WGS activity can be regarded as an indication of constant Ni surface area and therefore negligible Ni particle growth over the number of redox cycles. Ni/LST (Figure 6-b) showed maximal conversion already after a single reduction step. This was expected since all $\mathrm{Ni}$ is at the surface of the material and available for WGS catalysis on impregnated materials. Redox cycling shifted the conversion curves towards higher temperatures indicating catalytic activity loss, which is likely due to an initial $\mathrm{Ni}$ particle growth over the number of redox cycles. However, catalytic activity stabilized after four redox cycles (as documented by SEM in Figure 1). This effect can be related to the decreased driving force of particle sintering as particle growth progresses and/or to the stabilizing nature of the perovskite surface. The evolution of catalytic activity over consecutive redox cycles in both samples demonstrated the particle size stabilizing function of LSTN. Nevertheless, it is worth noticing that the final conversion curve of Ni/LST was still shifted to lower temperatures by around $50^{\circ} \mathrm{C}$ compared to the one obtained for LSTN after eight redox cycles, likely due to the larger amount of active $\mathrm{Ni}^{0}$ available on the surface of Ni/LST compared to LSTN as evident from XANES linear combination analysis (Figure 4-c). Since WGS activity is strongly dependent on Ni content, it is not surprising that $60 \mathrm{wt} \% \mathrm{Ni} / \mathrm{YSZ}$ showed the highest activity of all catalysts (Figure S5). Furthermore, redox cycling of Ni/YSZ did not affect catalytic activity towards WGS, which is a consequence of the high $\mathrm{Ni}$ content in this sample. However, in a working cell reoxidation of the $\mathrm{Ni} / \mathrm{YSZ}$ anode can be fatal and leads to mechanical fracture and cell failure due to the extreme volume expansion from $\mathrm{Ni}$ to $\mathrm{NiO}$ despite the fact that the material may preserve its high catalytic activity. ${ }^{21}$ Redox experiments on this material should therefore only be regarded as complementary to the ones performed on the LST-type catalysts. 


\subsection{Redox stable SOFC anode}

Fuel cell tests combined with detailed electrochemical analysis over a number of redox cycles were conducted on full button cells to investigate the performance and stability of LSTN during application as SOFC anode. Figure 7-a shows the current density and cell voltage under various operation conditions for $480 \mathrm{~h}$. Anode reoxidation was carried out nine times, after 21, 24, 27, 45, 48, 51, 190, $194 \mathrm{~h}$ and $313 \mathrm{~h}$, respectively, as indicated by vertical dashed time stamp lines. Reoxidation was carried out by a $\mathrm{H}_{2}$ fuel supply cut-off simulating a gas delivery stop or severe sealing failure. First, the cell was aged for $213 \mathrm{~h}$ under open circuit voltage (OCV) conditions (including the first eight redox treatments) before drawing $200 \mathrm{mAcm}^{-2}$ current from the cell under polarization. The polarization resistance development of the cell with time and number of redox cycles was investigated using electrochemical impedance spectroscopy (EIS). In the initial $213 \mathrm{~h}$ of the experiment redox stability of the LSTN-CGO material pair was tested by subjecting the cell to eight redox cycles under OCV. The Nyquist plot in Figure 7-b depicts impedance spectra before and after selected redox cycles throughout the thermal aging of the cell. Nyquist plots could be described as "compressed" semicircles indicating the existence of several overlapping processes. In the higher frequency ranges only a minor resistance contribution could be identified. This is mainly attributed to the cathode material, which has an optimized microstructure and long-term stability as demonstrated elsewhere. ${ }^{54-56}$ Because the cathode material exhibited a polarization resistance of $0.05 \Omega \mathrm{cm}^{2}$ in symmetrical cell tests thus contributing only marginally to the overall resistance, all changes in polarization resistance were assigned to the electrochemical processes occurring at the anode. It is important to highlight that the measured ohmic resistance of the cell was very close to the theoretical resistance of the $\mathrm{Sc}_{0.12} \mathrm{Zr}_{0.88} \mathrm{O}_{2}$ electrolyte and contributions from cell contacts and test rig itself did not affect the measurements. After the first two hours of aging at OCV a rather high area specific resistance (ASR) of $2.46 \Omega \mathrm{cm}^{2}$ was measured. This high resistance value was attributed to an insufficient reduction and thus limited exsolution of the 
catalytically active Ni. Cell performance remarkably improved after $21 \mathrm{~h}$ and a first redox cycle, which suggested the exsolution of larger amounts of Ni from bulk LSTN. The redox treatment caused a decrease in ASR to $0.82 \Omega \mathrm{cm}^{2}$. This behavior reflects the one observed during the catalytic tests on LSTN powders (Figure 6), where the first redox cycle also caused a large increase in catalytic activity indicating substantial increase in active Ni surface area over the first redox cycle.

A further decrease in ASR to $0.71 \Omega \mathrm{cm}^{2}$ was observed after the following two redox cycles. After $51 \mathrm{~h}$ of aging and six redox cycles, the ASR reached $0.60 \Omega \mathrm{cm}^{2}$, which was four times lower than the initial value measured at the beginning of the experiment. Performance loss accompanied by an ASR increase to $0.77 \Omega \mathrm{cm}^{2}$ was observed during further aging without redox cycling $\left(\mathrm{OCV}, 136 \mathrm{~h}, 850^{\circ} \mathrm{C}\right)$. However, the stimulus of two redox cycles again triggered the materials self-regeneration and led to a performance gain, which resulted in an ASR value of $0.72 \Omega \mathrm{cm}^{2}$ after $194 \mathrm{~h}$ at OCV and eight redox cycles. The analysis of differences in impedance spectra (ADIS), a data evaluation method in EIS, revealed information on the impact of redox cycling on electrochemical performance. ${ }^{57} \mathrm{~A}$ low frequency process in the range of 1-10 Hz (Figure S6) was attributed to the chemical capacitance, which was kinetically limited by the catalytic processes occurring at the surface of the mixed electronic ionic conductor such as LSTN and CGO (i.e. hydrogen oxidation reaction, HOR). Redox cycling, reverse potential mode $(-2.0 \mathrm{~V})$, as well as degradation during aging only affected this low frequency domain at $10 \mathrm{~Hz}$, which matches the previous observations. Long-term exposure of LSTN under OCV at $850{ }^{\circ} \mathrm{C}$ is expected to cause thermal growth of the Ni particles and hence loss of catalytic activity. In combination with the data from EXAFS and catalytic measurements, it is likely that the redox cycles triggered Ni regeneration. Therefore, the observed variation in the EIS spectra rather reflect the properties of the Ni particles as catalytic active phase in LSTN and is not believed to be related to the additional CGO phase. This claim is supported by the increase in cell performance and decrease of 
ASR with successive redox cycles and taking into account higher HOR activity of Ni compared to ceria. $^{58}$

An alternative approach to carry out a redox cycle is to subject the cell to a negative polarization of about $-2.0 \mathrm{~V}$ (electrolysis mode). The effect of electrolysis on the measured impedance is displayed in Figure 7-c and shows a narrowing of the Nyquist plot and decrease in ASR. ASR decreased to 0.65 $\Omega \mathrm{cm}^{2}$ as oxygen is actively drawn from the anode towards the air electrode at this potential and an oxygen partial pressure of about $10^{-30} \mathrm{~Pa}$ is typically reached. ${ }^{59}$ This highly reducing atmosphere likely provoked stronger reduction and increased $\mathrm{Ni}$ exsolution resulting in larger active Ni surface area and higher performance.
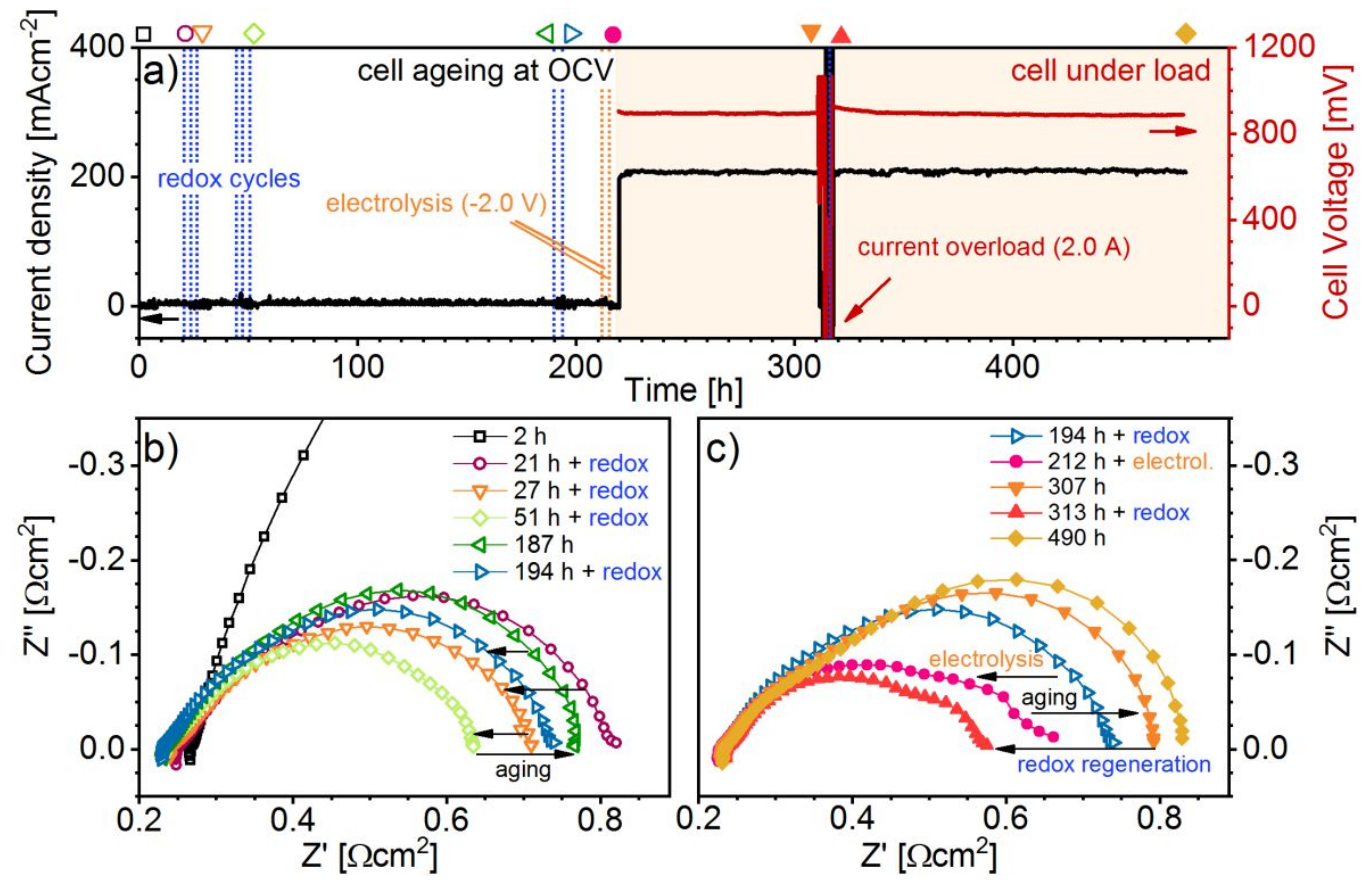

Figure 7. a) Current-Voltage characteristics and an overview of the conditions initiated during the longterm full cell test. White background - open circuit voltage (OCV) conditions, grey background dynamic conditions with cell polarization. Symbols on top represent the times of EIS corresponding measurements in b) and c). b) Electrochemical impedance spectroscopy data of $\mathrm{La}_{0.3} \mathrm{Sr}_{0.55} \mathrm{Ti}_{0.095} \mathrm{Ni}_{0.05} \mathrm{O}_{3}$ - $\mathrm{Ce}_{0.9} \mathrm{Gd}_{0.1} \mathrm{O}_{2}$ composite electrode operated under OCV conditions. c) Electrochemical impedance spectroscopy data measured for selected condition changes within the dynamic part of the experiment. 


\subsection{Recovery from sulfur poisoning}

Besides offering the possibility for cell operation in electrolysis mode, further potential benefits of the anode redox stability lie in the regeneration from sulfur poisoning, which is a severe problem for cells operated on $\mathrm{H}_{2}$ feeds. ${ }^{61}$ Sulfur poisoning becomes detrimental when WGS catalysis is needed to efficiently convert CO containing fuels. ${ }^{61}$ The effect of sulfur on the WGS activity of all catalyst 
samples was analyzed by further catalytic tests (Figure 8 and Figure S7). The sulfur recovery was tested after the redox cycles displayed in Figure 6 and Figure S5. After these redox stability tests the sample was treated with $50 \mathrm{ppm}$ of $\mathrm{H}_{2} \mathrm{~S}$ at $800^{\circ} \mathrm{C}$ for $2 \mathrm{~h}$ under reaction conditions. Finally, $\mathrm{CO}$ conversion profiles were recorded after sulfur poisoning and after two further redox (regeneration) cycles. While the already poor activity of Ni-free LST was not affected by the addition of sulfur (Figure S7-b), CO conversions on LSTN and Ni/LST decreased significantly. The sulfur treatment was also sufficient to extinguish the WGS reaction over Ni/YSZ (Figure S7-a) in agreement with the behavior of this anode material in the presence of sulfur. ${ }^{61}$ Even though both LSTN (Figure 8-a) and Ni/LST (Figure 8-b) suffered severely from sulfur poisoning, LSTN still retained some activity after poisoning, maintaining $25 \% \mathrm{CO}$ conversion at $800^{\circ} \mathrm{C}$. At this temperature $\mathrm{CO}$ conversion of poisoned $\mathrm{Ni} / \mathrm{LST}$ was as low as $10 \%$ and $5 \%$ conversion was found on Ni/YSZ. LSTN does not display as much $\mathrm{Ni}$ on its surface as either Ni/LST or Ni/YSZ and the fact that it showed the highest activity of the three after poisoning indicates that other WGS active sites than plain $\mathrm{Ni}^{0}$ may become important, likely as a result of the structural changes induced by Ni segregation.
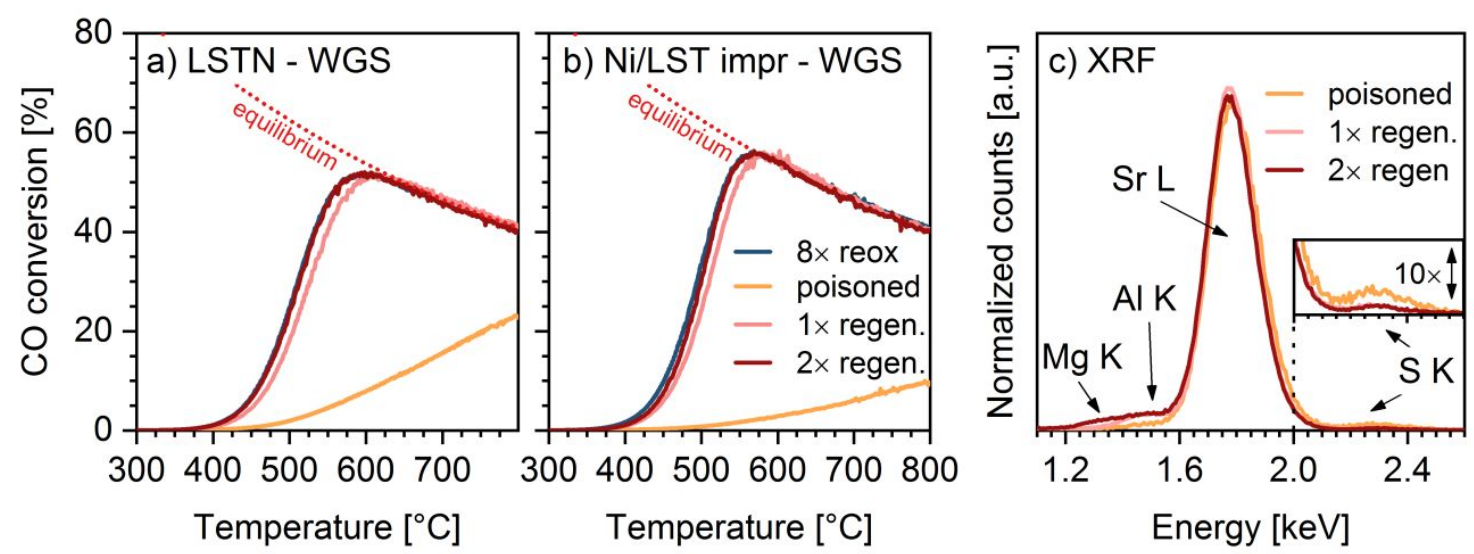

Figure 8. WGS activity profiles of (a) LSTN and (b) Ni/LST after eight redox cycles (prior to poisoning) as well as after $\mathrm{H}_{2} \mathrm{~S}$ poisoning and two oxidative catalyst regeneration cycles at $800^{\circ} \mathrm{C}$. Feed gas composition: $15 \mathrm{vol} \% \mathrm{CO}, 15 \mathrm{vol} \% \mathrm{H}_{2} \mathrm{O}, 7.5 \mathrm{vol} \% \mathrm{H}_{2}$, rest $\mathrm{Ar}$; at $30,000 \mathrm{mLh}^{-1} \mathrm{~g}^{-1}$ (at STP). The calculated theoretical conversion equilibrium is indicated by the dotted red curve. c) X-ray 
fluorescence $(1.1 \mathrm{keV}-2.6 \mathrm{keV})$ obtained on pellet samples of LSTN after $\mathrm{H}_{2} \mathrm{~S}$ poisoning and after two subsequent oxidative catalyst regeneration cycles at $800^{\circ} \mathrm{C}(2 \mathrm{~h}$ oxidation, $1 \mathrm{~h}$ reduction). The inset depicts a 10 fold magnification in intensity of the energy range $2.0 \mathrm{keV}-2.6 \mathrm{keV}$.

Redox cycling of poisoned LSTN, identical to the redox cycling exploited to demonstrate structural reversibility, restored its initial activity. The first regeneration cycle already recovered catalytic activity substantially, whereas a subsequent second regeneration cycle restored the $\mathrm{CO}$ conversion to the original levels obtained prior to poisoning. Ni/LST could also be regenerated to a large extent by subjecting it to similar regeneration cycles (Figure 8-b). However, complete regeneration was not achieved. Besides the fact that Ni/YSZ anodes usually cannot be regenerated by redox cycling due to their insufficient redox stability, ${ }^{21}$ it is also shown that regeneration of the material used as a catalyst was far from completion even after two regeneration cycles. Fresh Ni/YSZ showed significant activity below $400^{\circ} \mathrm{C}$, whereas after sulfur poisoning and two regeneration cycles comparable $\mathrm{CO}$ conversion was achieved only at higher temperatures $\left(\Delta \mathrm{T} \sim 50^{\circ} \mathrm{C}\right)$.

Figure 8-c shows X-ray fluorescence (XRF) spectra of LSTN after sulfur poisoning and over two regeneration cycles used to regenerate completely LSTN. Beside Mg K and Al K signals due to the Al sample holder and the presence of traces of the cordierite used to dilute the catalyst bed during catalytic testing, two additional signals could be identified. The Sr L-edge fluorescence signal $(1.8 \mathrm{keV})$ was by far the most prominent while a sulfur K-edge transition was clearly visible at $2.3 \mathrm{keV}$ in the poisoned sample. Despite the intensity decrease already after a single regeneration cycle, sulfur remained detectable after two cycles. Due to the presence of sulfur after catalyst regeneration and the observed complete recovery of WGS activity, it is likely that sulfur traces are deposited on the perovskite surface rather than on the catalytically active $\mathrm{Ni}$ and therefore did not interfere with catalytic activity. The exact nature of these species remains unsettled. From the perspective of the Ni phase in the same samples, the Ni K-edge spectra of the poisoned sample, of the sample prior to poisoning (after eight 
redox cycles) and after the complete regeneration cycles (reoxidation followed by reduction) overlapped completely (Figure S7). On the other hand, the spectrum of the reoxidised sample resembled the one of calcined LSTN. This clearly indicates that irrespective of sulfur poisoning Ni was able to reincorporate completely during the oxidative treatment of the redox cycle and segregated from the perovskite lattice upon the reductive treatment to restore the catalytically active Ni particles with a sulfur free surface and to regenerate catalytic activity.

\section{Conclusions}

A redox stable and active Ni based SOFC anode material is presented, which does not make use of precious metals to obtain sulfur tolerance. The cost efficient material exhibits the remarkable property of structural regeneration where $\mathrm{Ni}$ can be reversibly exsoluted from the bulk of the perovskite-type mixed oxide through reduction and reincorporated back into the host lattice by reoxidation. The structural reversibility upon redox cycling was documented at microstructure scales as well as on the atomistic level by means of electron microscopy (SEM/TEM/EDX) and with various spectroscopy techniques (EXAFS, XANES, XRD). In addition, the associated reversibility of the catalytic activity was demonstrated by catalytic tests including e.g. WGS activity and TPR profiles. It is shown that Ni exsolution from the perovskite-type host oxide results in the formation of nano scale Ni particles active for the water gas shift reaction, which is important to achieve high efficiencies on fuel cells operated on syngas fuels. Structural reversibility (i.e. the reincorporation of Ni back into the host lattice) can be exploited to regenerate the anode layer after aging, which is known to cause deactivation of current SOFC anodes through Ni particle growth. Redox cycling even activated the $\mathrm{La}_{0.3} \mathrm{Sr}_{0.55} \mathrm{Ti}_{0.95} \mathrm{Ni}_{0.05} \mathrm{O}_{3-\delta}$ anode material and it was demonstrated that catalytic activity of the material towards the water gas shift reaction could be completely restored after the catalyst had suffered from poisoning by sulfur. It is for the first time that a material with the properties required for SOFC anode applications was 
demonstrated to also exhibit the remarkable structural regeneration after sulfur poisoning with the result of a precious metal free, stable and regenerable SOFC anode layer.

\section{Acknowledgements}

The authors kindly acknowledge the financial support from the Competence Center for Energy and Mobility (CCEM), the Swiss National Science Foundation (SNF, No. 200021_159568). HEXIS AG is thanked for their financial contribution, support and providing fuel cell test facilities. This research project is part of the Swiss Competence Center for Energy Research SCCER BIOSWEET of the Swiss Innovation Agency lnnosuisse. The Swiss Light Source is thanked for the provision of beam times at the SuperXAS and Phoenix I beamlines and Dr. M. Nachtegaal, Dr. C. Borca, Dr. T. Huthwelker and M. Elsener are gratefully acknowledged for their extensive and kind support.

\section{Supplementary information}

List of catalysts compositions and denotations including primary and secondary crystal phases. XRD patterns of samples after calcination, reduction, reoxidization and reduction after 8 redox cycles. $\mathrm{H}_{2}-$ TPR profiles. Linear combination fit of XANES spectra. $\mathrm{k}^{3}$-weighted EXAFS spectra. CO conversion profiles of Ni/YSZ and $\mathrm{Ni}$ free LST before and after $\mathrm{H}_{2} \mathrm{~S}$ poisoning. Analysis of Differences in Impedance Spectra (ADIS). Normalized Ni K-edge XANES spectra of LSTN after sulfur poisoning and after regeneration. 


\section{References}

1. Park, S. D.; Vohs, J. M.; Gorte, R. J., Direct oxidation of hydrocarbons in a solid-oxide fuel cell. Nature 2000, 404 (6775), 265-267.

2. Ormerod, R. M., Solid oxide fuel cells. Chem. Soc. Rev. 2003, 32 (1), 17-28.

3. Eguchi, K.; Kojo, H.; Takeguchi, T.; Kikuchi, R.; Sasaki, K., Fuel flexibility in power generation by solid oxide fuel cells. Solid State Ionics 2002, 152, 411-416.

4. Yi, Y. F.; Rao, A. D.; Brouwer, J.; Samuelsen, G. S., Fuel flexibility study of an integrated 25 kW SOFC reformer system. J. Power Sources 2005, 144 (1), 67-76.

5. Lo Faro, M.; Antonucci, V.; Antonucci, P. L.; Arico, A. S., Fuel flexibility: A key challenge for SOFC technology. Fuel 2012, 102, 554-559.

6. Dicks, A. L., Advances in catalysts for internal reforming in high temperature fuel cells. J. Power Sources 1998, 71 (1-2), 111-122.

7. Meusinger, J.; Riensche, E.; Stimming, U., Reforming of natural gas in solid oxide fuel cell systems. J. Power Sources 1998, 71 (1-2), 315-320.

8. Baschuk, J. J.; Li, X. G., Carbon monoxide poisoning of proton exchange membrane fuel cells. Int. J. Energ. Res. 2001, 25 (8), 695-713.

9. Weber, A.; Sauer, B.; Muller, A. C.; Herbstritt, D.; Ivers-Tiffee, E., Oxidation of $\mathrm{H}_{2}$, $\mathrm{CO}$ and methane in SOFCs with Ni/YSZ-cermet anodes. Solid State Ionics 2002, 152, 543550 .

10. Minh, N. Q., Ceramic fuel cells. J. Am. Ceram. Soc. 1993, 76 (3), 563-588.

11. Dees, D. W.; Claar, T. D.; Easler, T. E.; Fee, D. C.; Mrazek, F. C., Conductivity of porous $\mathrm{Ni} / \mathrm{ZrO}_{2}-\mathrm{Y}_{2} \mathrm{O}_{3}$ cermets. J. Electrochem. Soc. 1987, 134 (9), 2141-2146.

12. Atkinson, A.; Barnett, S.; Gorte, R. J.; Irvine, J. T. S.; Mcevoy, A. J.; Mogensen, M.; Singhal, S. C.; Vohs, J., Advanced anodes for high-temperature fuel cells. Nat. Mater. 2004, 3 (1), 17-27.

13. Cassidy, M.; Lindsay, G.; Kendall, K., The reduction of nickel-zirconia cermet anodes and the effects on supported thin electrolytes. J. Power Sources 1996, 61 (1-2), 189-192.

14. Faes, A.; Hessler-Wyser, A.; Zryd, A.; Van herle, J., A review of redox cycling of solid oxide fuel cells anode. Membranes 2012, 2, 585-664.

15. Madi, H.; Diethelm, S.; Ludwig, C.; Van herle, J., Organic-sulfur poisoning of solid oxide fuel cell operated on bio-syngas. Int. J. Hydrogen Energ. 2016, 41 (28), 12231-12241. 
16. Kuhn, J. N.; Lakshminarayanan, N.; Ozkan, U. S., Effect of hydrogen sulfide on the catalytic activity of Ni-YSZ cermets. J. Mol. Catal. A 2008, 282 (1-2), 9-21.

17. Dong, J.; Cheng, Z.; Zha, S. W.; Liu, M. L., Identification of nickel sulfides on NiYSZ cermet exposed to $\mathrm{H}_{2}$ fuel containing $\mathrm{H}_{2} \mathrm{~S}$ using Raman spectroscopy. J. Power Sources 2006, 156 (2), 461-465.

18. Yang, L.; Cheng, Z.; Liu, M. L.; Wilson, L., New insights into sulfur poisoning behavior of Ni-YSZ anode from long-term operation of anode-supported SOFCs. Energ. Environ. Sci. 2010, 3 (11), 1804-1809.

19. Lussier, A.; Sofie, S.; Dvorak, J.; Idzerda, Y. U., Mechanism for SOFC anode degradation from hydrogen sulfide exposure. Int. J. Hydrogen Energ. 2008, 33 (14), 39453951.

20. Malzbender, J.; Wessel, E.; Steinbrech, R. W., Reduction and re-oxidation of anodes for solid oxide fuel cells. Solid State Ionics 2005, 176 (29-30), 2201-2203.

21. Sarantaridis, D.; Atkinson, A., Redox cycling of Ni-based solid oxide fuel cell anodes: a review. Fuel Cells 2007, 7 (3), 246-258.

22. Holzer, L.; Iwanschitz, B.; Hocker, T.; Munch, B.; Prestat, M.; Wiedenmann, D.; Vogt, U.; Holtappels, P.; Sfeir, J.; Mai, A.; Graule, T., Microstructure degradation of cermet anodes for solid oxide fuel cells: quantification of nickel grain growth in dry and in humid atmospheres. J. Power Sources 2011, 196 (3), 1279-1294.

23. Marina, O. A.; Canfield, N. L.; Stevenson, J. W., Thermal, electrical, and electrocatalytical properties of lanthanum-doped strontium titanate. Solid State Ionics 2002, 149 (1-2), 21-28.

24. Tao, S. W.; Irvine, J. T. S., A redox-stable efficient anode for solid-oxide fuel cells. Nat. Mater. 2003, 2 (5), 320-323.

25. Verbraeken, M. C.; Iwanschitz, B.; Mai, A.; Irvine, J. T. S., Evaluation of Ca doped $\mathrm{La}_{0.2} \mathrm{Sr}_{0.7} \mathrm{TiO}_{3}$ as an alternative material for use in SOFC anodes. J. Electrochem. Soc. 2012, 159 (11), 757-762.

26. Yoo, K. B.; Choi, G. M., Performance of La-doped strontium titanate (LST) anode on LaGaO3-based SOFC. Solid State Ionics 2009, 180 (11-13), 867-871.

27. Boulfrad, S.; Cassidy, M.; Traversa, E.; Irvine, J. T. S., Improving the Performance of SOFC Anodes by Decorating Perovskite with Ni Nanoparticles. Solid Oxide Fuel Cells 13 (SOFC-XIII) 2013, 57 (1), 1211-1216. 
28. Neagu, D.; Oh, T. S.; Miller, D. N.; Ménard, H.; Bukhari, S. M.; Gamble, S. R.; Gorte, R. J.; Vohs, J. M.; Irvine, J. T. S., Nano-socketed nickel particles with enhanced coking resistance grown in situ by redox exsolution. Nat. Commun. 2015, 6, 1-8.

29. Jardiel, T.; Caldes, M. T.; Moser, F.; Hamon, J.; Gauthier, G.; Joubert, O., New SOFC electrode materials: the Ni-substituted LSCM-based compounds $\left(\mathrm{La}_{0.75} \mathrm{Sr}_{0.25}\right)\left(\mathrm{Cr}_{0.5} \mathrm{Mn}_{0.5-}\right.$ $\left.{ }_{\mathrm{x}} \mathrm{Ni}_{\mathrm{x}}\right) \mathrm{O}_{3-\mathrm{d}}$ and $\left(\mathrm{La}_{0.75} \mathrm{Sr}_{0.25}\right)\left(\mathrm{Cr}_{0.5-\mathrm{x}} \mathrm{Ni}_{\mathrm{x}} \mathrm{Mn}_{0.5}\right) \mathrm{O}_{3-\mathrm{d}}$. Solid State Ionics 2010, 181 (19-20), 894-901.

30. Burnat, D.; Kontic, R.; Holzer, L.; Steiger, P.; Ferri, D.; Heel, A., Smart material concept: reversible microstructural self-regeneration for catalytic applications. J. Mater. Chem. A 2016, 4 (30), 11939-11948.

31. Arrivé, C.; Delahaye, T.; Joubert, O.; Gauthier, G., Exsolution of nickel nanoparticles at the surface of a conducting titanate as potential hydrogen electrode material for solid oxide electrochemical cells. J. Power Sources 2013, 223, 341-348.

32. Oh, T. S.; Rahani, E. K.; Neagu, D.; Irvine, J. T. S.; Shenoy, V. B.; Gorte, R. J.; Vohs, J. M., Evidence and model for strain-driven release of metal nanocatalysts from perovskites during exsolution. J. Phys. Chem. Lett. 2015, 6 (24), 5106-5110.

33. Tanaka, H.; Taniguchi, M.; Uenishi, M.; Kajita, N.; Tan, I.; Nishihata, Y.; Mizuki, J.; Narita, K.; Kimura, M.; Kaneko, K., Self-regenerating Rh- and Pt-based perovskite catalysts for automotive-emissions control. Angew. Chem. Int. Edit. 2006, 45 (36), 5998-6002.

34. Nishihata, Y.; Mizuki, J.; Akao, T.; Tanaka, H.; Uenishi, M.; Kimura, M.; Okamoto, T.; Hamada, N., Self-regeneration of a Pd-perovskite catalyst for automotive emissions control. Nature 2002, 418 (6894), 164-167.

35. Kuc, J.; Zhang, Y. C.; Erni, R.; Yoon, S.; Karvonen, L.; Weidenkaff, A.; Matam, S. K., Composition dependent self-regenerative property of perovskite-type oxides. Phys. Status Solidi RRL 2015, 9 (5), 282-287.

36. Eyssler, A.; Winkler, A.; Safonova, O.; Nachtegaal, M.; Matam, S. K.; Hug, P.; Weidenkaff, A.; Ferri, D., On the state of $\mathrm{Pd}$ in perovskite-type oxidation catalysts of composition $\mathrm{A}(\mathrm{B}, \mathrm{Pd}) \mathrm{O}_{3 \pm d}(\mathrm{~A}=\mathrm{La}, \mathrm{Y} ; \mathrm{B}=\mathrm{Mn}, \mathrm{Fe}, \mathrm{Co})$. Chem. Mater. 2012, 24 (10), 18641875.

37. Lai, K.-Y.; Manthiram, A., Self-regenerating Co-Fe nanoparticles on perovskite oxides as a hydrocarbon fuel oxidation catalyst in solid oxide fuel cells. Chem. Mater. 2018, 30, 2515-2525.

38. Steiger, P.; Delmelle, R.; Foppiano, D.; Holzer, L.; Heel, A.; Nachtegaal, M.; Krocher, O.; Ferri, D., Structural Reversibility and Nickel Particle stability in Lanthanum Iron Nickel Perovskite-Type Catalysts. ChemSusChem 2017, 10 (11), 2505-2517. 
39. Deng, J.; Cai, M. D.; Sun, W. J.; Liao, X. M.; Chu, W.; Zhao, X. S., Oxidative methane reforming with an intelligent catalyst: sintering-tolerant supported nickel nanoparticles. ChemSusChem 2013, 6 (11), 2061-2065.

40. Sun, Y. F.; Li, J. H.; Zeng, Y. M.; Amirkhiz, B. S.; Wang, M. N.; Behnamian, Y.; Luo, J. L., A-site deficient perovskite: the parent for in situ exsolution of highly active, regenerable nano-particles as SOFC anodes. J. Mater. Chem. A 2015, 3 (20), 11048-11056.

41. Ravel, B.; Newville, M., ATHENA, ARTEMIS, HEPHAESTUS: data analysis for Xray absorption spectroscopy using IFEFFIT. J. Synchrotron Radiat. 2005, 12, 537-541.

42. Marschner, F. M., F. W., In Applied Industrial Catalysis, Leach, B. E., Ed. Academic Press: New York, 1983; Vol. 2, p 215.

43. Holzer, L.; Munch, B.; Iwanschitz, B.; Cantoni, M.; Hocker, T.; Graule, T., Quantitative relationships between composition, particle size, triple phase boundary length and surface area in nickel-cermet anodes for solid oxide fuel cells. J. Power Sources 2011, 196 (17), 7076-7089.

44. Faes, A.; Hessler-Wyser, A.; Presvytes, D.; Vayenas, C. G.; Van herle, J., Nickelzirconia anode degradation and triple phase boundary quantification from microstructural analysis. Fuel Cells 2009, 9 (6), 841-851.

45. Burnat, D.; Ried, P.; Holtappels, P.; Heel, A.; Graule, T.; Kata, D., The rheology of stabilised lanthanum strontium cobaltite ferrite nanopowders in organic medium applicable as screen printed SOFC cathode layers. Fuel Cells 2010, 10 (1), 156-165.

46. Burnat, D.; Heel, A.; Holzer, L.; Otal, E.; Kata, D.; Graule, T., On the chemical interaction of nanoscale lanthanum doped strontium titanates with common scandium and yttrium stabilized electrolyte materials. Int. J. Hydrogen Energ. 2012, 37 (23), 18326-18341.

47. Hjalmarsson, P.; Sun, X. F.; Liu, Y. L.; Chen, M., Influence of the oxygen electrode and inter-diffusion barrier on the degradation of solid oxide electrolysis cells. J. Power Sources 2013, 223, 349-357.

48. Megaw, H. D., Crystal structure of double oxides of the perovskite type. Proc. Phys. Soc. 1946, 58 (326), 133-152.

49. Tanaka, H.; Tan, I.; Uenishi, M.; Taniguchi, M.; Nishihata, Y.; Mizuki, J., The intelligent catalyst: $\mathrm{Pd}$-perovskite having the self-regenerative function in a wide temperature range. Key Eng. Mater. 2006, 317-318, 827-832.

50. Mile, B.; Stirling, D.; Zammitt, M. A.; Lovell, A.; Webb, M., The location of nickeloxide and nickel in silica-supported catalysts - 2 forms of $\mathrm{NiO}$ and the assignment of temperature-programmed reduction profiles. J. Catal. 1988, 114 (2), 217-229. 
51. Wachsman, E. D.; Lee, K. T., Lowering the temperature of solid oxide fuel cells. Science 2011, 334 (6058), 935-939.

52. Stobbe, E. R.; de Boer, B. A.; Geus, J. W., The reduction and oxidation behaviour of manganese oxides. Catal. Today 1999, 47 (1-4), 161-167.

53. Matsuzaki, Y.; Yasuda, I., Electrochemical oxidation of $\mathrm{H}_{2}$ and $\mathrm{CO}$ in a $\mathrm{H}_{2}-\mathrm{H}_{2} \mathrm{O}-\mathrm{CO}-\mathrm{CO}_{2}$ system at the interface of a Ni-YSZ cermet electrode and YSZ electrolyte. J. Electrochem. Soc. 2000, 147 (5), 1630-1635.

54. Holzer, L.; Iwanschitz, B.; Hocker, T.; Munch, B.; Presta, M.; Wiedenmann, D.; Vogt, U.; Holtappels, P.; Sfeir, J.; Mai, A.; Graule, T., Microstructure degradation of cermet anodes for solid oxide fuel cells: quantification of nickel grain growth in dry and in humid atmospheres. J. Power Sources 2011, 196 (3), 1279-1294.

55. Iwanschitz, B.; Holzer, L.; Mai, A.; Schutze, M., Nickel agglomeration in solid oxide fuel cells: the influence of temperature. Solid State Ionics 2012, 211, 69-73.

56. Iwanschitz, B.; Sfeir, J.; Mai, A.; Schutze, M., Degradation of SOFC anodes upon redox cycling: a comparison between Ni/YSZ and Ni/CGO. J. Electrochem. Soc. 2010, 157 (2), B269-B278.

57. Burnat, D.; Nurk, G.; Holzer, L.; Kopecki, M.; Heel, A., Lanthanum doped strontium titanate - ceria anodes: deconvolution of impedance spectra and relationship with composition and microstructure. J. Power Sources 2018, 385, 62-75.

58. Primdahl, S.; Mogensen, M., Mixed conductor anodes: Ni as electrocatalyst for hydrogen conversion. Solid State Ionics 2002, 152, 597-608.

59. Ye, L.; Zhang, M.; Huang, P.; Guo, G.; Hong, M.; Li, C.; Irvine, J. T. S.; Xie, K., Enhancing $\mathrm{CO}_{2}$ electrolysis through synergistic control of non-stoichiometry and doping to tune cathode surface structures. Nat. Commun. 2017, 8 .

60. Comminges, C.; Fu, Q. X.; Zahid, M.; Steiner, N. Y.; Bucheli, O., Monitoring the degradation of a solid oxide fuel cell stack during $10,000 \mathrm{~h}$ via electrochemical impedance spectroscopy. Electrochim. Acta 2012, 59, 367-375.

61. Hagen, A., Sulfur poisoning of the water gas shift reaction on anode supported solid oxide fuel cells. J. Electrochem. Soc. 2013, 160 (2), F111-F118. 


\section{Table of Content}

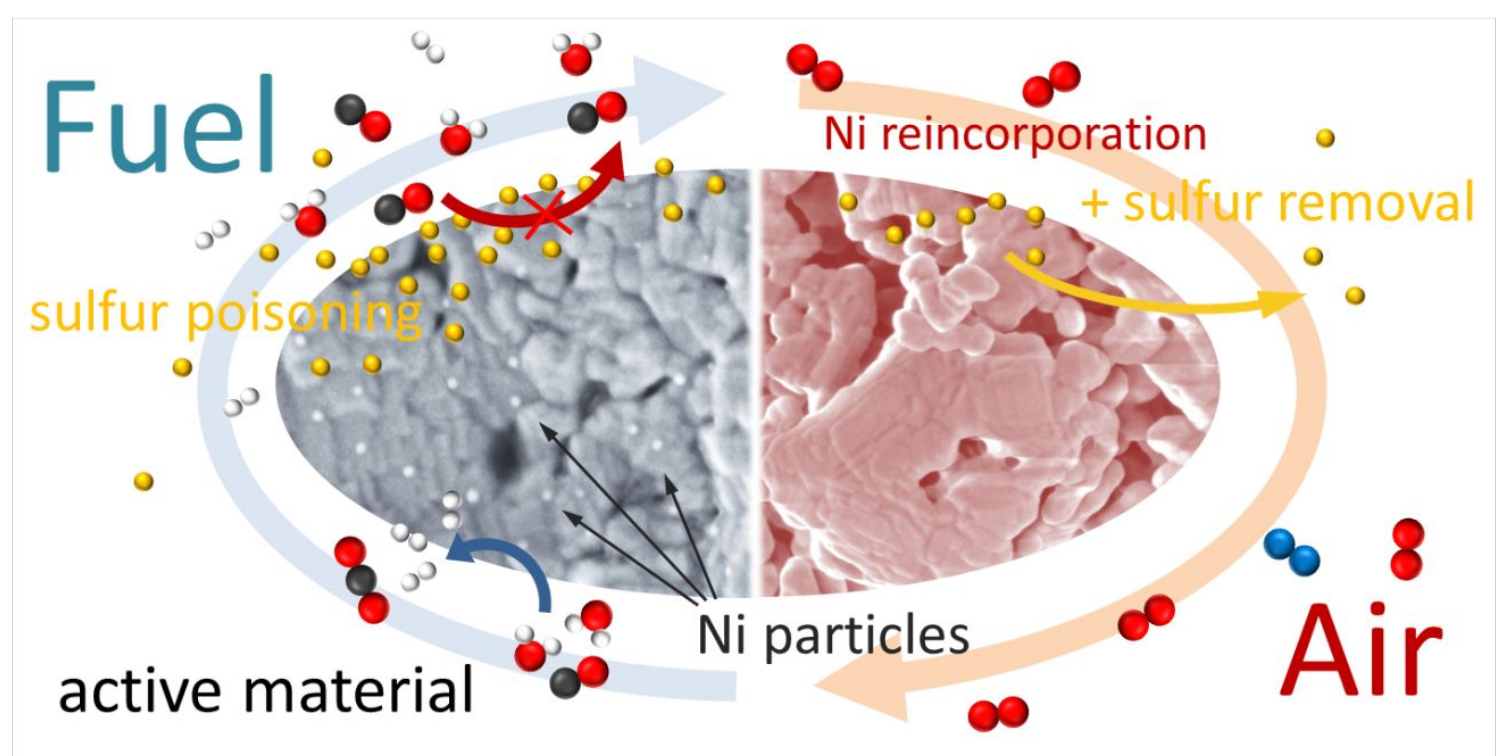

